\title{
A Combined Scientometric and Critical Approach in Reviewing TiZr Implant Alloys and Coating Performances
}

\author{
Radu Nartita ${ }^{1}$ (D), Daniela Ionita ${ }^{2}$ and Ioana Demetrescu ${ }^{1,2, *(D)}$ \\ 1 Department of General Chemistry, Faculty of Applied Chemistry and Material Science, \\ University Polithenica of Bucharest, 313 Splaiul Indepentei, 060042 Bucharest, Romania; \\ nartita.radu@gmail.com \\ 2 Academy of Romanian Scientists, Ilfov Street, 3, 050044 Bucharest, Romania; daniela.ionita@upb.ro \\ * Correspondence: i_demetrescu@chim.upb.ro
}

check for updates

Citation: Nartita, R.; Ionita, D.;

Demetrescu, I. A Combined

Scientometric and Critical Approach in Reviewing TiZr Implant Alloys and Coating Performances. Coatings 2021, 11, 392. https://doi.org/10.3390/ coatings11040392

Academic Editor: Grzegorz Dercz

Received: 13 March 2021

Accepted: 27 March 2021

Published: 30 March 2021

Publisher's Note: MDPI stays neutral with regard to jurisdictional claims in published maps and institutional affiliations.

Copyright: (c) 2021 by the authors. Licensee MDPI, Basel, Switzerland. This article is an open access article distributed under the terms and conditions of the Creative Commons Attribution (CC BY) license (https:// creativecommons.org/licenses/by/ $4.0 /)$.

\begin{abstract}
This review article was developed based on the scientometric analysis of the evaluated studies conducted on titanium-zirconium $\left(\mathrm{Ti}_{x} \mathrm{Zr}\right.$ ) alloys from 2000 to the present. The scientometric data obtained helped us to identify the most researched topics and these topics were further analyzed and discussed. An increasing number of researchers are considering $\mathrm{Ti}_{x} \mathrm{Zr}$ alloys as opposed to the traditional ones because these alloys present improved mechanical properties and in some cases improved corrosion resistance and biocompatibility. Due to the natural layer of oxides formed on these alloys, multiple surface modification methods can be applied to solve some of the challenges faced in the field of implantable materials. A significant number of studies are now focusing on surface modifications at the nanometer scale or various coatings for improved corrosion resistance and biological interactions. Although not yet commercially available, a TiZr alloy with a nanostructured surface and embedded biologically active substances, such as antibiotics or coated with hydroxyapatite, may become a future option.
\end{abstract}

Keywords: TiZr alloy; titanium zirconium alloy; surface modification; nanostructured surfaces; scientometric analysis

\section{Introduction}

Due to the good biocompatibility of $\mathrm{Ti}$, research on $\mathrm{Ti}$ alloys used as biomaterials is on a continuous upward trend [1,2]. A radical increase in research related to zirconium dioxide $\left(\mathrm{ZrO}_{2}\right)$ has also been observed due to increased mechanical strength, biocompatibility, and aesthetic properties in the case of dental work [1,3]. In this context, the titanium-zirconium $\left(\mathrm{Ti}_{x} \mathrm{Zr}\right)$ alloys have been intensively investigated in the last decade.

The mechanical properties, porosity, surface morphology, and implant design are the determining factors for the evolution of osseointegration and longevity of an implant $[4,5]$.

Implantable materials must have mechanical properties such as a modulus of elasticity, yield strength, and ultimate tensile strength that can withstand various biomechanical forces. Besides, biomaterials must be biocompatible, have low density and increased resistance to corrosion and wear [6].

Commercially pure titanium (cpTi) was the most attractive alternative for implants $[7,8]$. However, the manufacture of implants with small diameters $(\leq 3.5 \mathrm{~mm})$ from cp-Ti is associated with an increased risk of fracture due to insufficient mechanical strength. The aim is to develop new alloys and coatings to solve this problem [8-14].

$\mathrm{Zr}$ as Ti is situated in Group IV of the periodic table of elements, therefore the two elements have similar chemical properties and biocompatibilities $[15,16]$. Thus, $\mathrm{Ti}_{x} \mathrm{Zr}$ type alloys began to be studied more and more frequently, with the possibility to solve these problems, as both have satisfactory mechanical properties and good biocompatibility [10,17-20].

It is known that a new alloying strategy involving the combination of several principal elements in high concentrations has been in development in the few years. The goal is to 
elaborate new materials named high entropy alloys with remarkable properties exceeding those of conventional alloys. Some of them contain $\mathrm{Ti}$ and $\mathrm{Zr}$ [21-23] and have potential implant applications [24].

Compared to other traditional biomaterials, some of the binary $\mathrm{Ti}_{x} \mathrm{Zr}$ alloys have a higher strength/weight ratio, lower modulus of elasticity and better corrosion resistance [25-27]. Moreover, on the surface of alloys containing titanium and zirconium, a layer of apatite is formed that is structurally similar to bone tissue, which improves the bioactivity of these materials [28,29].

The present manuscript has a novel approach being a combined scientometric and critical one in reviewing the behavior of TiZr alloys based on their composition, surface and interface.

\section{Methods}

A bibliographic search was conducted in the ScienceDirect database using the terms "titanium zirconium implants" and "TiZr implants", choosing only the "research" and "review" articles published in English from 2000 to the present (5 February 2021). Additionally, to ensure that most of the relevant studies regarding the chosen topic were taken into consideration, multiple articles were selected manually.

The selected articles were carefully analyzed considering the purpose of this review article. The inclusion criteria involved studies that examined binary $\mathrm{Ti}_{x} \mathrm{Zr}$ alloys or those that studied relevant characteristics related to the surface of this type of alloy. The aspects monitored and evaluated were those related to changes at the micro and nanometric scale, the methods used, mechanical properties, corrosion resistance and biological interactions.

The VOSviewer software (version: 1.6.16) was used for the scientometric analysis. The evaluated aspects are co-authorship (unit of analysis: authors), co-occurrence of keywords and terms from titles and abstracts. In all three cases, the maps created from the network analysis were based on the selected bibliographic data.

For the authors to be included in the co-authorship analysis, a minimum number of 2 articles was selected for the keywords to be included in the co-occurrence analysis, a minimum number of 2 occurrences was selected and for the terms from titles and abstracts, a minimum number of 10 occurrences was selected.

\section{Results and Discussions}

The search identified 2508 articles in the ScienceDirect database. After reading the titles and abstracts, 2344 were excluded. The remaining 164 articles were further evaluated, from which 128 articles were selected based on the inclusion criteria. Another 35 articles were selected manually. The selection process is illustrated in Figure 1.

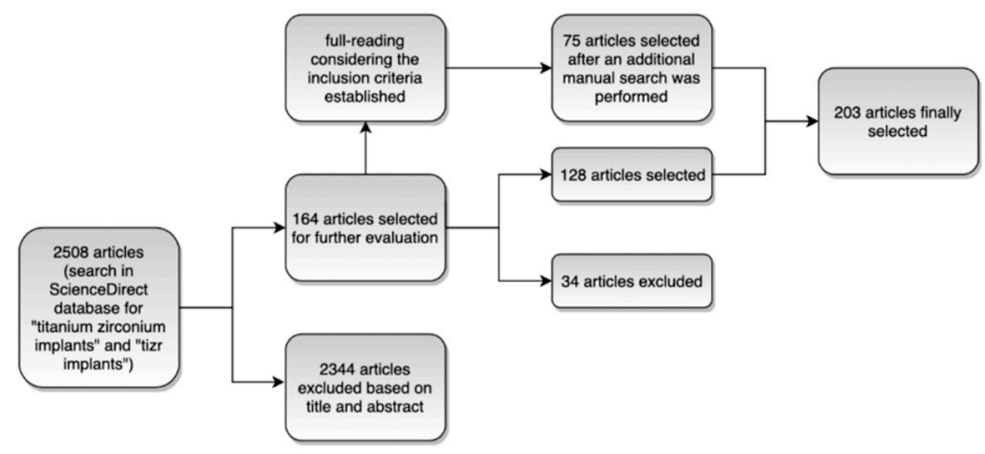

Figure 1. Evaluation process.

\subsection{Scientometric Analysis}

For the scientometric analysis we decided upon visual representations coupled with some quantitative data. In the networks constructed, the link between two authors indicates that they have co-authored publications, while the strength of a link indicates the number 
of co-authored publications. In the case of terms used (keywords or other terms), the link indicates that the terms co-occur in the same publication, while the strength of the link indicates the number of publications in which the terms co-occur.

\subsubsection{Co-Authorship}

From the total of 858 authors, 100 meet the threshold. The map is presented in Figure 2. The highest number of publications for the analyzed data was 20 with a corresponding total link strength of 70, while the lowest was two with zero total link strength.

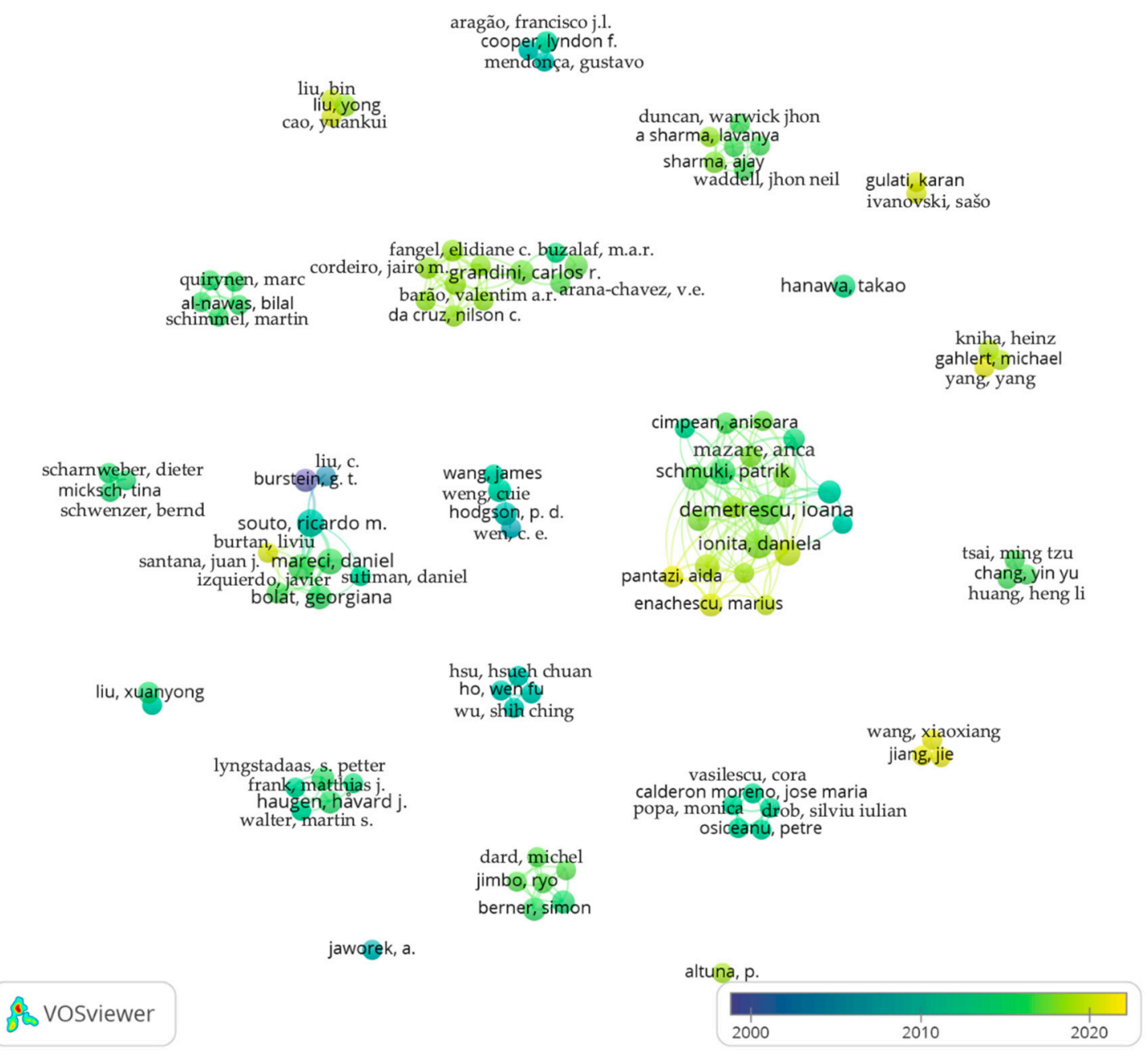

Figure 2. Co-authorship network.

It can be observed from the obtained data that multiple, groups of authors are studying metallic biomaterials and in particular titanium alloys, such as $\mathrm{Ti}_{x} \mathrm{Zr}$. Additionally, an increasing trend can be observed in the last few years, compared with the starting period considered.

\subsubsection{Co-Occurrence}

From the total of 586 keywords, 121 meet the threshold. The map is presented in Figure 3, while the top 10 keywords based on total link strength are presented in Table 1.

Overall, the combined data suggest that the $\mathrm{Ti}_{x} \mathrm{Zr}$ type of alloys are intensively studied as an alternative for the conventional ones. Additionally, a trend is observed in the direction of nanostructured surface modifications with antibacterial properties. 


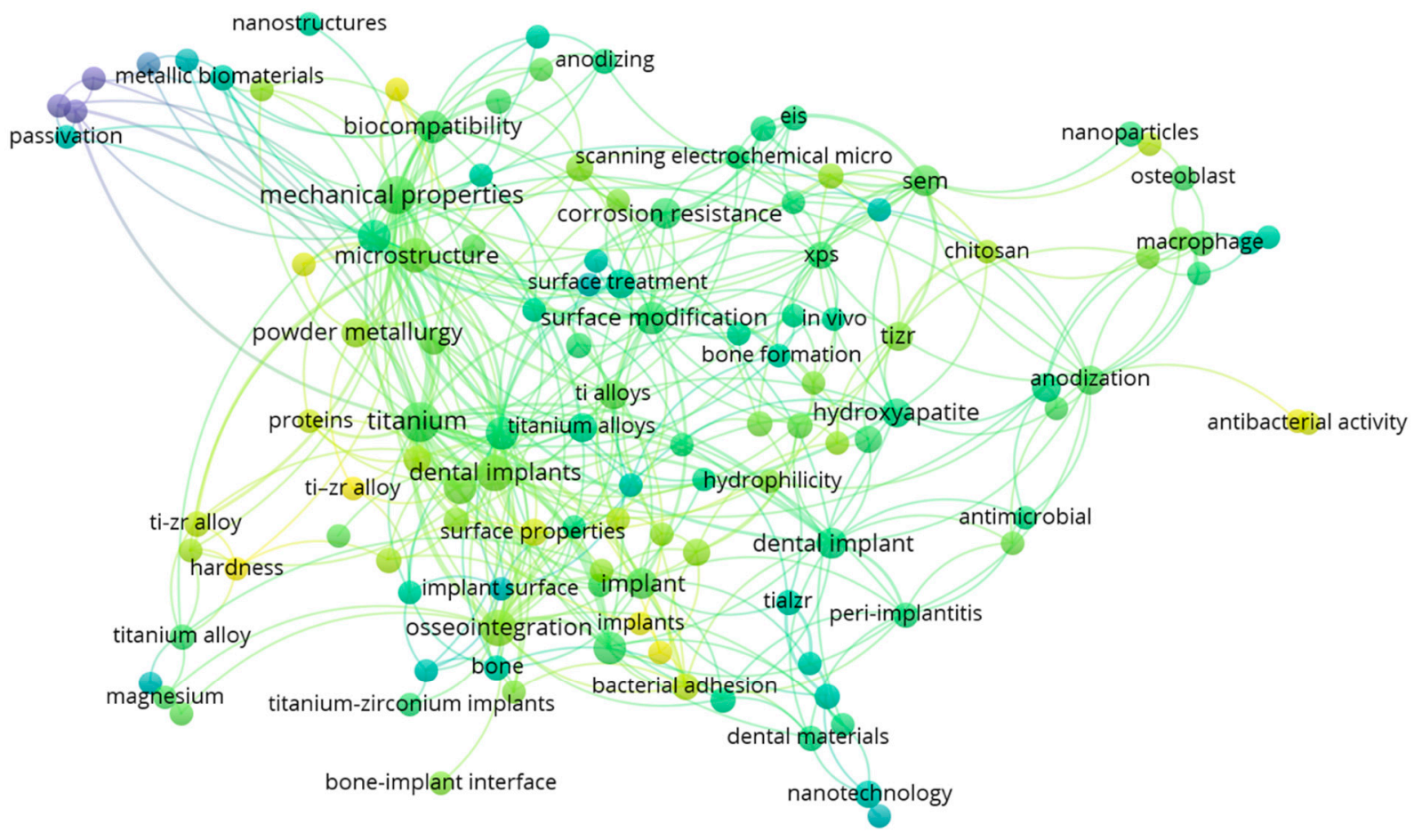

Posviewer

$2000+2020$

Figure 3. Co-occurrence of keywords.

Table 1. Top 10 keywords based on total link strength from the selected bibliography.

\begin{tabular}{ccc}
\hline Keyword & Occurrences & Total Link Strength \\
\hline Titanium & 31 & 70 \\
Mechanical properties & 22 & 52 \\
Dental implants & 15 & 42 \\
Osseointegration & 15 & 38 \\
Corrosion & 10 & 36 \\
Microstructure & 12 & 30 \\
Surface modification & 10 & 28 \\
Biocompatibility & 11 & 25 \\
Biomaterials & 11 & 24 \\
Zirconium & 10 & 22 \\
\hline
\end{tabular}

Some limitations regarding the quantitative data come from the different name attributed to the same subject. As it can be seen in the visual representation, $\mathrm{Ti}_{x} \mathrm{Zr}$ alloys have been named "ti-zr alloy", "tizr", "tizr alloy", which indicate a much higher value for occurrences and the total link strength in this case.

The larger, central nodes indicate that the keywords were more frequently found, which also implies that the research on that particular subject began a long time ago (e.g., titanium, dental implants, osseointegration). In contrast, the marginal nodes indicate either that the topics have started to be studied more recently (e.g., antibacterial activity, bacterial adhesion, bone-implant interface, nanostructures) or that the topics were studied in the past. These aspects are also visible in the color of the nodes, which is based on the year of publishing. Moreover, the links between the nodes highlight the correlation between the subjects. 


\subsubsection{Co-Occurrence (Terms from Titles and Abstracts)}

From the total of 4947 terms, 128 meet the threshold. For each of the 128 terms the software calculates a relevance score to eliminate the general terms that have no useful information. Based on this score, $60 \%$ most relevant terms were selected, resulting in seven terms. Even so, some usual terms such as "day", "contact", "week" etc. were included. Therefore, these terms were excluded manually to obtain only the relevant terms. Finally, several two terms were selected. The map is presented in Figure 4, while the top 15 terms based on occurrences are presented in Table 2.

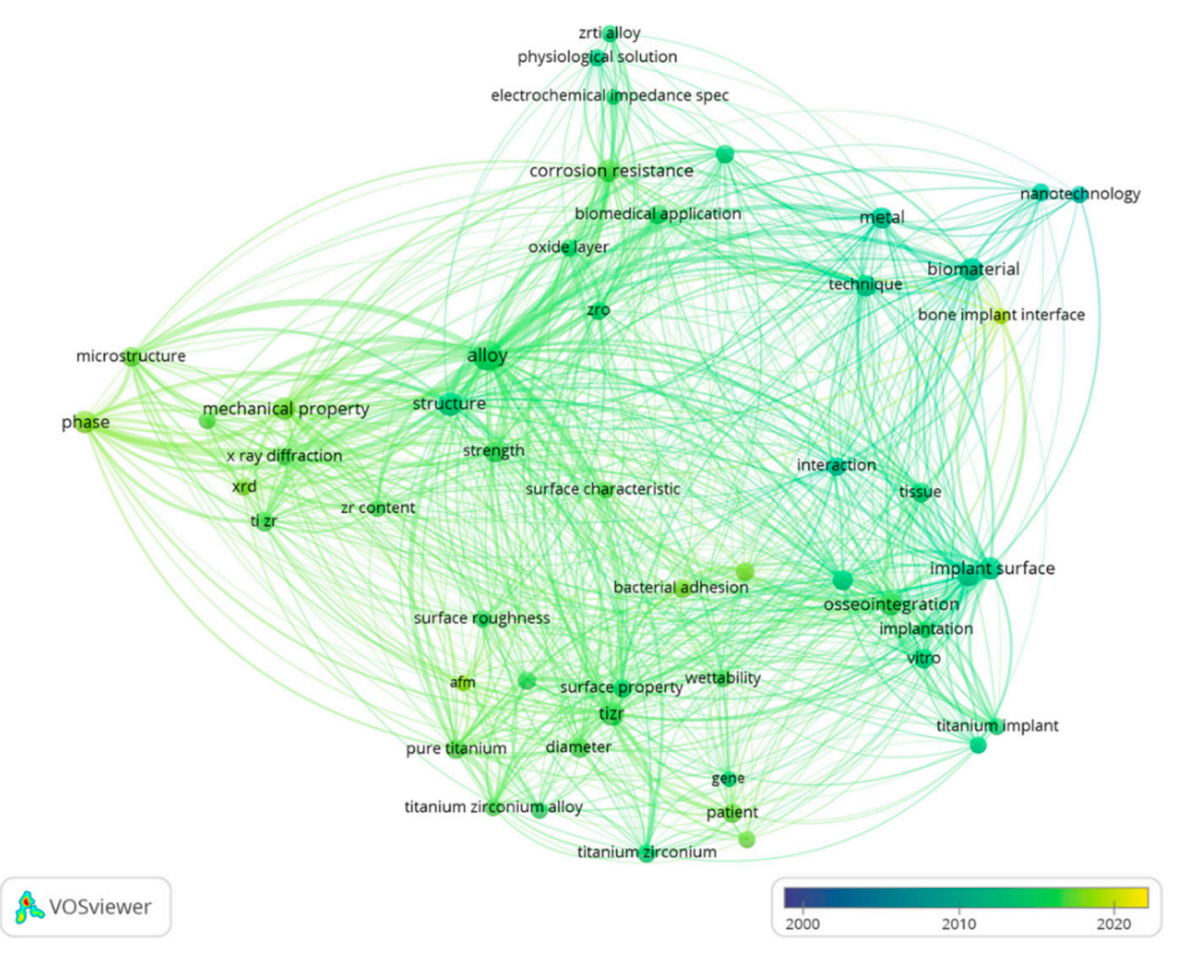

Figure 4. Co-occurrence of terms from titles and abstracts.

Table 2. Top 15 terms from titles and abstracts based on occurrences from the selected bibliography.

\begin{tabular}{cc}
\hline Term & Occurrences \\
\hline Alloy & 288 \\
tizr & 94 \\
structure & 78 \\
mechanical property & 65 \\
biomaterial & 60 \\
corrosion resistance & 59 \\
implant surface & 57 \\
phase & 57 \\
osseointegration & 57 \\
metal & 51 \\
bone & 47 \\
technique & 45 \\
strength & 39 \\
ti zr & 36 \\
biomedical application & 36 \\
\hline
\end{tabular}

The co-occurrence of terms from titles and abstracts indicates furthermore the main subjects of interest. By analyzing the data provided in the visual representation through the size of nodes, the links between them and their color it can be concluded that different alloys are increasingly studied as biomaterials. The mechanical properties and the corrosion 
resistance of these alloys appear to be mentioned more throughout time, but an interest regarding surface modifications in relation to different biological aspects seems to emerge in more recent studies.

The top terms combined with the visual representation helped us to establish the most studied topics that are followed throughout this article such as type of alloy, mechanical properties, surface modifications and biocompatibility.

\subsection{Properties Related to the Composition of $\mathrm{Ti}_{x} \mathrm{Zr}$ Alloys}

Bone tissue is a type of connective tissue made up of cells and fibers. From the perspective of mechanical properties, two types of bone tissue are differentiated, namely cortical and trabecular. Cortical bone has a higher density and low porosity $(10 \%)$, having a modulus of elasticity between 4-30 GPa and a compressive strength between 20-193 MPa. The trabecular bone has a low density, being composed in a proportion of $50-90 \%$ from pores. This is also reflected in the modulus of elasticity which is between $0.2-2 \mathrm{GPa}$ and the compressive strength which is between $2-80 \mathrm{MPa}$ [30]. The modulus of elasticity of biomaterials should be close to that of the bones. If the biomaterial presents a significantly higher modulus of elasticity, a phenomenon known as stress shield may occur, which is characterized by a reduction in bone density (osteopenia) [28].

The interstitial elements, carbon $(\mathrm{C})$, oxygen $(\mathrm{O})$, nitrogen $(\mathrm{N})$ and hydrogen $(\mathrm{H})$ have a hardening effect on transition metals due to the high suppression of dislocation movements and network distortion [31]. Of these, $\mathrm{O}$ has the highest solubility in $\mathrm{Ti}$ and a considerable hardening effect. In $\mathrm{Ti}_{x} \mathrm{Zr}$ alloys, an increase in hardness has been reported with an increase in $\mathrm{O}$ content [31,32]. Additionally, increasing the concentration of $\mathrm{Zr}$ leads to finer grains, which together with the strengthening of the solid solution leads to increased hardness, strength and plasticity. At the same time, an increased performance regarding osteoinduction is obtained due to better adhesion of proteins [10].

Zirconium is considered an isomorphic stabilizer being completely soluble in $\mathrm{Ti}$, it can exist in both pure $\alpha$ and $\beta$ phase [33]. In solid solution with another $\beta$ stabilizer, $\mathrm{Zr}$ can also act as a $\beta$ stabilizer [34]. The $\alpha$ and $\alpha-\beta$ mix phases have good strength and creep resistance, but $\beta$ alloys have a better fatigue strength and lower Young's modulus [33]. The $\mathrm{Zr}$ content in the allotropic form $\alpha^{\prime}$ (hexagonal martensite) increases the modulus of elasticity [35]. While the $\alpha$ phase has small benefits at the temperature and stress associated with implants, the $\beta$ phase is especially beneficial for orthopedic implants and any long-term implant $[33,36]$.

As high entropy alloys (HEAs) have exceptional mechanical and corrosion behavior new phases derived from the AlCoFeNiSmTiVZr [37] and from $\mathrm{Ti}-\mathrm{Nb}-\mathrm{Ta}-\mathrm{Zr}$ after $\mathrm{Al}$ addition have also been investigated [38] establishing the formation of the intermetallic phase after annealing at $600-1200^{\circ} \mathrm{C}$.

A study performed on $\mathrm{Ti}_{x} \mathrm{Zr}$ alloys $(x=10,20,30,40 \mathrm{wt} . \%$ ) shows that the microhardness values, the bending strengths and the elastic recovery angles increase with the content of $\mathrm{Zr}$, being much higher compared to cpTi [2]. In the case of increasing the $\mathrm{Zr}$ content, in $\mathrm{Zr}_{x} \mathrm{Ti}$ alloys $(x=10,20,30,40 \mathrm{wt} . \%)$ the properties no longer vary constantly with the Ti content. Among the studied alloys, the best values of microhardness and bending modulus were reported for $\mathrm{Ti}-40 \mathrm{Zr}$ wt.\% [39]. $\mathrm{Ti}_{x} \mathrm{Zr}$ binary alloys with high $\mathrm{Zr}$ content also present high strength [40]. The hardness of $\mathrm{Ti}_{50} \mathrm{Zr}$ alloy (at.\%) is 2.5 times higher than pure Ti or $\mathrm{Zr}$ [28,41].

Current information shows that TiZr alloys can also be manufactured to have a porous structure and mechanical properties similar to those of bone tissue [29,42,43]. Wen et al. report the manufacture of TiZr alloy foams with a density of approximately 0.3 and pores of $200-500 \mu \mathrm{m}$. The Young's modulus for these is between 78.4 MPa and 15.3 GPa [29]. Porous bulk metallic glass based on Ti-Zr has also been studied as an alternative to conventional materials [44,45].

Comparative analysis regarding the mechanical properties between different studies was difficult to perform for several reasons. On the one hand, different alloy manufacturing techniques affect their structure and thus their mechanical properties, even if the composition 
of the alloys is the same. On the other hand, the evaluated characteristics and the evaluation methods differ, which induces a greater variability. However, an attempt was made to summarize the data and draw some conclusions. The observations are found in Table 3.

It can be seen that $\mathrm{Ti}_{x} \mathrm{Zr}$ type alloys and especially $\mathrm{Ti}_{50} \mathrm{Zr}$ have improved mechanical properties compared to the constituent metals.

In other studies, it is also remarked that the mechanical properties of Ti are superior to $\mathrm{Zr}$, as well as those of osseointegration, but $\mathrm{Zr}$ is superior to Ti regarding bacterial adhesion [46]. The addition of $\mathrm{Zr}$ in Ti increases the hardness due to the transformation of the structure from $\alpha$ (hexagonal) to $\alpha^{\prime}$ (orthorhombic) [47]. The microhardness, mechanical strength and plasticity also increase with increasing $\mathrm{Zr}$ content [48]. $\mathrm{Ti}_{50} \mathrm{Zr}$ presents significantly increased hardness due to solid solution strengthening, an effect caused by the differences between the atomic radii of $\mathrm{Ti}$ and $\mathrm{Zr}$ [41] and increased corrosion resistance compared to the individual metals ( $\mathrm{Zr}$ or $\mathrm{Ti}$ ) [49]. It is noted as well that the addition of $\mathrm{Zr}$ significantly increases the corrosion resistance, but up to a maximum content of $50 \%$ $\mathrm{Zr}$ [50]. In terms of biocompatibility, $\mathrm{Ti}_{x} \mathrm{Zr}$ alloys present similar properties compared to Ti [51] or even better [12].

Table 3. Comparative aspects $\mathrm{Ti}-\mathrm{Ti}_{x} \mathrm{Zr}-\mathrm{Zr}$.

\begin{tabular}{|c|c|c|c|c|c|c|c|c|}
\hline Parameter & $\mathrm{Ti}$ & $\begin{array}{c}\text { Ti15Zr } \\
\text { (Roxolid) }\end{array}$ & $\begin{array}{c}\operatorname{Ti}_{x} \operatorname{Zr}(x=10 \\
20,30,40 \text { wt. } \%)\end{array}$ & $\begin{array}{l}\operatorname{Ti}_{x} \mathrm{Zr}(x=5,15 \\
25,35,45 \mathrm{wt} \%)\end{array}$ & Ti-50Zr & $\begin{array}{c}\mathrm{Zr}_{x} \operatorname{Ti}(x=10 \\
20,30,40 \text { wt. } \%)\end{array}$ & Zr-30Ti & $\mathrm{Zr}$ \\
\hline Hardness & $\begin{array}{l}102-109 \\
\text { HV [52] }\end{array}$ & $\begin{array}{c}197 \mathrm{HV} \\
{[52]}\end{array}$ & - & $\begin{array}{c}473 \\
\text { HV(Ti5Zr)-525 } \\
\text { HV(Ti45Zr) [53] }\end{array}$ & - & - & $\begin{array}{l}275-447 \\
\text { HV [54] }\end{array}$ & - \\
\hline Microhardness & $\begin{array}{c}186 \mathrm{HV} \\
{[2]}\end{array}$ & - & $\begin{array}{c}266 \\
\text { HV(Ti10Zr)-350 } \\
\text { HV(Ti40Zr) [2] }\end{array}$ & - & - & $\begin{array}{c}275 \\
\text { HV(Zr30Ti)-291 } \\
\text { HV(Zr10Ti) [39] }\end{array}$ & - & $\begin{array}{c}175 \mathrm{HV} \\
{[39]}\end{array}$ \\
\hline Hardness & $\begin{array}{c}1630 \mathrm{MPa} \\
{[55]}\end{array}$ & - & - & - & $\begin{array}{c}6.2 \mathrm{GPa} \text { (bulk) } \\
2.01-3.00 \mathrm{GPa} \\
\text { (nanotubes) [19] }\end{array}$ & - & - & $\begin{array}{c}700 \mathrm{Mpa} \\
{[55]}\end{array}$ \\
\hline $\begin{array}{l}\text { Modulus of } \\
\text { elasticity }\end{array}$ & $\begin{array}{c}103 \mathrm{GPa} \\
{[53]}\end{array}$ & - & - & $\begin{array}{c}53.5-59.3 \mathrm{GPa} \\
{[53]}\end{array}$ & 44 GPa [28] & - & $\begin{array}{c}\text { 68-130 } \\
\text { Gpa [54] }\end{array}$ & - \\
\hline $\begin{array}{l}\text { Bending } \\
\text { strength }\end{array}$ & $\begin{array}{c}844 \mathrm{Mpa} \\
{[2]}\end{array}$ & - & $\begin{array}{c}989 \mathrm{MPa} \\
\text { (Ti10Zr)-1628 } \\
\mathrm{MPa}(\mathrm{Ti} 40 \mathrm{Zr}) \text { [2] }\end{array}$ & - & - & $\begin{array}{c}1258-1738 \mathrm{MPa} \\
{[39]}\end{array}$ & - & $\begin{array}{c}1142 \\
\text { Mpa [39] }\end{array}$ \\
\hline
\end{tabular}

\subsection{Surface of $\mathrm{Ti}_{x} \mathrm{Zr}$ Alloys}

Material surface is of particular importance regarding the interaction with the body. This should stimulate the integration with the surrounding tissue and prevent bacterial adhesion and colonization. Obtaining these characteristics is a difficult task because the surfaces of biomaterials that facilitate cell adhesion are also favorable for the adhesion of bacteria, the mechanisms being similar [56,57].

The physicochemical properties of the implant surface directly influence the formation of new bone tissue. This phenomenon is known as contact osteogenesis. Thus, over time, several types of implants have been studied, from solid and macroporous to modified surfaces at the micrometric, submicrometric and more recently, nanometric scale [58].

Surface characteristics are generally separated into two categories, topographic and chemical. Topographic characteristics refer to the surface roughness, which can be evaluated by several parameters, of which the most commonly used is $R_{a}$, the arithmetic mean of deviations from the mean line. Three-dimensional parameters are also used, such as $\mathrm{S}_{\mathrm{a}}$, which represents the arithmetic mean of deviations from the mean plane of analysis. A problem in evaluating this parameter is that these measurement techniques are developed for flat surfaces and are less suitable for threaded implants, such as screws [59].

As the surface is the only region that comes into contact with bone tissue, much of the studies have focused on modifying certain properties such as chemical composition and 
roughness to promote osseointegration and mechanical fixation. The increase in roughness leads to a larger contact surface for proteins and cells to interact with the material [60]. In contrast, the metallic biomaterials that are designed to come into direct contact with whole blood (heart valves, heart aid devices, heart pumps) must have low thrombogenicity [61] and high surface roughness, as well as high surface energy, which is associated with high thrombogenicity $[9,62]$. Thus, when designing the biomaterial surfaces multiple aspects must be considered.

Surface chemistry is relevant through composition, biocompatible metals such as $\mathrm{Ti}$ and $\mathrm{Zr}$, being valve metals, form a natural layer of oxides that represent a barrier in the corrosion process, but also through other properties such as surface energy or surface charge. It is important to note that changes in topography often induce changes in chemistry, or vice versa $[59,63,64]$. $\mathrm{Ti}_{x} \mathrm{Zr}$ type alloys have a better wettability than $\mathrm{cpTi}$, which leads to a different biological behavior [17]. Studies suggest that surfaces with higher hydrophilicity lead to better tissue integration, osseointegration and faster healing [65].

Surface modifications of metallic biomaterials mainly aim at increasing corrosion resistance and improving bioactivity $[30,66,67]$. Additionaaly, because after surgery there is an increased risk of developing a bacterial infection and oral antibiotics are generally given, a more effective alternative could be to load implants with active substances that act locally, over time $[7,12,68-70]$.

The techniques used can be mechanical, chemical or physical. Mechanical methods include grinding, polishing and blasting. Chemical methods include treatments with acids, hydrogen peroxide, alkaline solutions, sol-gel techniques, anodic oxidation, micro-arc oxidation (MAO) and chemical vapor deposition. Physical methods include physical vapor deposition, femtosecond laser ablation in solution (FLAS) and several types of thermal spraying methods [71-77].

The naturally formed oxide film on the surface of $\mathrm{Ti}$ is composed of several layers, namely $\mathrm{TiO}$ (in contact with the metal), $\mathrm{Ti}_{2} \mathrm{O}_{3}$ (intermediate layer) and $\mathrm{TiO}_{2}$ (outer layer). Oxidation processes can increase the concentration of $\mathrm{TiO}_{2}$ quite a lot so that the layers of suboxides can no longer be detected, but the organization exists [74].

Oxidic compounds formed by the natural phenomenon of passivation may result from the following oxidation reactions [25]:

$$
\begin{gathered}
\mathrm{Ti}+\mathrm{H}_{2} \mathrm{O} \rightarrow \mathrm{TiO}+2 \mathrm{H}^{+}+2 \mathrm{e}^{-} \\
2 \mathrm{TiO}+\mathrm{H}_{2} \mathrm{O} \rightarrow \mathrm{Ti}_{2} \mathrm{O}_{3}+2 \mathrm{H}^{+}+2 \mathrm{e}^{-} \\
\mathrm{Ti}_{2} \mathrm{O}_{3}+\mathrm{H}_{2} \mathrm{O} \rightarrow \mathrm{TiO}_{2}+2 \mathrm{H}^{+}+2 \mathrm{e}^{-} \\
2 \mathrm{Zr}+\mathrm{H}_{2} \mathrm{O} \rightarrow \mathrm{Zr}_{2} \mathrm{O}+2 \mathrm{H}^{+}+2 \mathrm{e}^{-} \\
\mathrm{Zr}_{2} \mathrm{O}+\mathrm{H}_{2} \mathrm{O} \rightarrow 2 \mathrm{ZrO}+2 \mathrm{H}^{+}+2 \mathrm{e}^{-} \\
2 \mathrm{ZrO}+\mathrm{H}_{2} \mathrm{O} \rightarrow \mathrm{Zr}_{2} \mathrm{O}_{3}+2 \mathrm{H}^{+}+2 \mathrm{e}^{-} \\
\mathrm{Zr}_{2} \mathrm{O}_{3}+\mathrm{H}_{2} \mathrm{O} \rightarrow 2 \mathrm{ZrO}_{2}+2 \mathrm{H}^{+}+2 \mathrm{e}^{-}
\end{gathered}
$$

The Gibbs free energy for $\mathrm{Zr}$ oxidation $(-1117.8 \mathrm{~kJ} / \mathrm{mol})$ is greater than that for $\mathrm{Ti}$ oxidation $(-890.5 \mathrm{~kJ} / \mathrm{mol})$, which suggests that $\mathrm{Zr}$ is preferentially oxidized [78]. However, a study performed on the oxide film developed by $\mathrm{Ti}_{50} \mathrm{Zr}$ alloys (at.\%) through anodization $(9 \mathrm{~V})$ in different solutions shows that the mobility of $\mathrm{Ti}^{4+}$ ions is higher than that of $\mathrm{Zr}^{4+}$ ions, the outer layer being composed mostly of $\mathrm{TiO}_{2}$. The average reported composition was $76 \% \mathrm{TiO}_{2}$ and $24 \% \mathrm{ZrO}_{2}$ [79]. This aspect is revealed in another study on $\mathrm{Ti}_{x} \mathrm{Zr}$ alloys $\left(x=23,42,62.5\right.$ at.\%), showing that the outer layer is composed of $\mathrm{TiO}_{2}$ and that it decreases in thickness with increasing $\mathrm{Zr}$ content. The reported composition of the inner layers was $\left(\mathrm{Ti}_{0.74} \mathrm{Zr}_{0.26}\right) \mathrm{O}_{2},\left(\mathrm{Ti}_{0.56} \mathrm{Zr}_{0.44}\right) \mathrm{O}_{2}$, and $\left(\mathrm{Ti}_{0.365} \mathrm{Zr}_{0.635}\right) \mathrm{O}_{2}$ [80].

The methods used to modify the surfaces of $\mathrm{Ti}_{x} \mathrm{Zr}$ alloys mentioned in the literature, as well as some relevant aspects are summarized in Table 4 . 
Table 4. Methods for surface modifications.

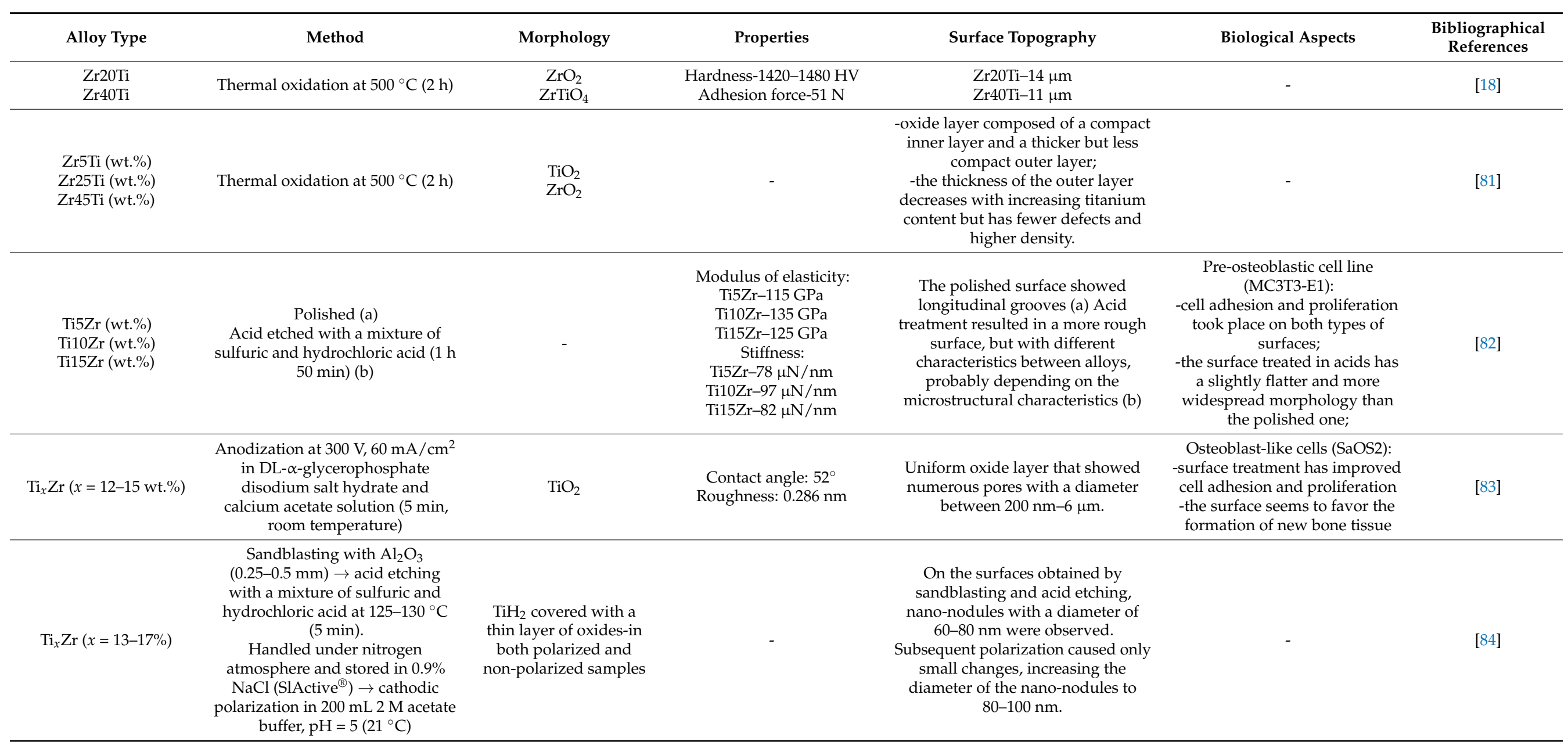


Table 4. Cont.

\begin{tabular}{|c|c|c|c|c|c|c|}
\hline Alloy Type & Method & Morphology & Properties & Surface Topography & Biological Aspects & $\begin{array}{l}\text { Bibliographical } \\
\text { References }\end{array}$ \\
\hline $\mathrm{Ti}_{15} \mathrm{Zr}(\mathrm{wt} . \%)$ & $\begin{array}{c}\text { Polishing } \rightarrow \text { plasma electrolytic } \\
\text { oxidation (PEO). The electrolyte } \\
\text { solution was prepared from Ca } \\
\text { acetate and disodium glycerol } \\
\text { phosphate. }\end{array}$ & $\begin{array}{l}\mathrm{TiO}_{2} \\
\mathrm{ZrO}_{2}\end{array}$ & Contact angle: $30^{\circ}$ & $\begin{array}{l}\text { Rough surface with pores of } \\
\text { different diameters }\end{array}$ & $\begin{array}{l}\text { Albumin adsorption and } \\
\text { adhesion of Streptococcus } \\
\text { sanguinis were evaluated: } \\
\text {-improved protein adsorption } \\
\text {-low adhesion of the biofilm }\end{array}$ & [85] \\
\hline $\mathrm{Ti}_{20} \mathrm{Zr}($ wt. $\%)$ & $\begin{array}{l}\text { Polishing } \rightarrow \text { galvanostatic } \\
\text { anodization in } 0.3 \mathrm{M} \text { and } 1 \mathrm{M} \\
\text { phosphoric acid solution }\end{array}$ & $\begin{array}{c}\mathrm{TiO}_{2} \\
\mathrm{ZrO}_{2} \\
\text { Phosphate ions } \\
\text { incorporated into the } \\
\text { oxide layer }\end{array}$ & - & $\begin{array}{l}\text { The oxide layer increased in } \\
\text { thickness through anodization; } \\
\text { The incorporation of phosphate ions } \\
\text { increases corrosion resistance. }\end{array}$ & - & [86] \\
\hline $\begin{array}{c}\mathrm{Ti}_{x} \mathrm{Zr}(x=10,20,30 \\
40 \text { wt.\%) }\end{array}$ & $\begin{array}{c}\text { Heat treatment at } 1000^{\circ} \mathrm{C}(24 \mathrm{~h}) \text { in } \\
\text { argon atmosphere } \rightarrow \text { polishing } \rightarrow \\
\text { anodization in } 1.0 \mathrm{M} \mathrm{H}_{3} \mathrm{PO}_{4}+ \\
0.5 \mathrm{wt} . \% \mathrm{NaF}\end{array}$ & $\begin{array}{l}\mathrm{TiO}_{2} \\
\mathrm{ZrO}_{2}\end{array}$ & - & $\begin{array}{c}\text { Nanotubes with an internal } \\
\text { diameter between } 150-200 \mathrm{~nm} \text {, wall } \\
\text { thickness- } 20 \mathrm{~nm} \text {. } \\
\text { The distance between the nanotubes } \\
\text { increases with the } \mathrm{Zr} \text { content }(60 \mathrm{~nm} \text {, } \\
70 \mathrm{~nm}, 100 \mathrm{~nm}, 130 \mathrm{~nm}) \text {. } \\
\text { Nanotube length increases with } \mathrm{Zr} \\
\text { content }(800 \mathrm{~nm}, 1.25 \mu \mathrm{m}, 1.7 \mu \mathrm{m}, \\
1.9 \mu \mathrm{m})\end{array}$ & - & [87] \\
\hline $\mathrm{Ti}_{50} \mathrm{Zr}$ & $\begin{array}{c}\text { Polishing } \rightarrow \text { two-step anodization } \\
\text { in glycerin }+15 \% \mathrm{H}_{2} \mathrm{O}+0.2 \mathrm{M} \\
\mathrm{NH}_{4} \mathrm{~F} \text {, with ultrasonication } \\
\text { between the two stages } \rightarrow \\
\text { annealing at } 4500^{\circ} \mathrm{C}\end{array}$ & $\begin{array}{c}\mathrm{Ti}_{0.67} \mathrm{Zr}_{0.33} \text { (without } \\
\text { annealing) } \\
\mathrm{ZrTiO}_{4} \\
\text { (with annealing) }\end{array}$ & $\begin{array}{c}\text { Contact angle- }-\mathrm{H}_{2} \mathrm{O}: 29.2^{\circ} \\
\text { Adhesion force: } 12.4 \mathrm{nN} \\
\text { Hardness: } 1.02-1.24 \mathrm{GPa} \\
\text { Modulus of elasticity: } \\
\text { 28-43 GPa } \\
\text { Contact angle- }-\mathrm{H}_{2} \mathrm{O}: 29.6^{\circ} \\
\text { Adhesion force: } 10.9 \mathrm{nN} \\
\text { Hardness: } 0.90-0.97 \mathrm{GPa} \\
\text { Modulus of elasticity: } \\
\text { 26-27 GPa }\end{array}$ & $\begin{array}{l}\text { Nanotubes with a diameter between } \\
\qquad 46-120 \mathrm{~nm}\end{array}$ & $\begin{array}{c}\text { The antibacterial effect on } \\
\text { Staphylococcus aureus (S. aureus) } \\
\text { was studied: } \\
\text {-the nanotubular texture } \\
\text { inhibited growth by } 65-69 \%\end{array}$ & [89] \\
\hline
\end{tabular}


Table 4. Cont.

\begin{tabular}{|c|c|c|c|c|c|c|}
\hline Alloy Type & Method & Morphology & Properties & Surface Topography & Biological Aspects & $\begin{array}{l}\text { Bibliographical } \\
\text { References }\end{array}$ \\
\hline $\mathrm{Ti}_{50} \mathrm{Zr}$ & $\begin{array}{c}\text { Polishing } \rightarrow \text { two-step anodization } \\
\text { in glycerin }+15 \% \mathrm{H}_{2} \mathrm{O}+0.2 \mathrm{M} \\
\mathrm{NH}_{4} \mathrm{~F} \text {, with ultrasonication } \\
\text { between the two stages } \rightarrow \\
\text { application of gentamicin sulfate } \\
\text { solution } \rightarrow \text { coating with chitosan } \\
(\mathrm{CS}) \text { by immersion }(1) \\
\text { Surfaces treated as described in (1) } \\
\text { were immersed in a mixture of } \\
\text { sulfuric acid-hydrogen peroxide } \\
\text { for } 2 \mathrm{~h}(2) \text {. }\end{array}$ & - & $\begin{array}{l}\text { (1) Contact angle: } 30^{\circ} \\
\text { (1) Roughness: } 319 \mathrm{~nm} \\
\text { (2) Contact angle: } 52.5^{\circ} \\
\text { (2) Roughness: } 440 \mathrm{~nm}\end{array}$ & $\begin{array}{l}\text { (1) Nanotubes with internal } \\
\text { diameter } 120 \mathrm{~nm} \text {, external diameter } \\
230 \mathrm{~nm} \text {, wall thickness } 30 \mathrm{~nm} \text { and } \\
\text { length } 10 \mu \mathrm{m} \\
\text { (2) Nanopores with a diameter of } 70 \\
\mathrm{~nm} \text { and a depth of } 100 \mathrm{~nm} .\end{array}$ & $\begin{array}{l}\text { (1) In the case of nanotubes, } 68 \% \\
\text { of gentamicin is released in a } \\
\text { first stage, faster, and the rest in } \\
\text { a slower stage up to } 21 \text { days. } \\
\text { (2) In the case of nanopores, } 82 \% \\
\text { of gentamicin is released in the } \\
\text { first } 60 \mathrm{~h} \text {, and the rest gradually } \\
\text { up to } 10 \text { days. }\end{array}$ & [68] \\
\hline $\mathrm{Ti}_{50} \mathrm{Zr}(\mathrm{wt} . \%)$ & $\begin{array}{c}\text { Polishing } \rightarrow \text { acid etching in } \\
\mathrm{HNO}_{3}: \mathrm{HF}: \mathrm{H}_{2} \mathrm{O} \text { mixture }(3: 1: 2) \\
\rightarrow \text { anodization in } \\
\mathrm{K}_{2} \mathrm{HPO}_{4} / \text { glycerol at } 180{ }^{\circ} \mathrm{C}(2 \mathrm{~h})\end{array}$ & $\begin{array}{c}\mathrm{TiO}_{2} \\
\mathrm{ZrO}_{2} \\
\left(\mathrm{Zr}_{x} \mathrm{Ti}_{y} \mathrm{O}_{z}\right)\end{array}$ & Contact angle: $15^{\circ}$ & $\begin{array}{l}\text { Nanochannels with a diameter of } 35 \\
\mathrm{~nm} \text { and a length of } 3.2 \mu \mathrm{m}\end{array}$ & $\begin{array}{l}\text { RAW } 264.7 \text { macrophages: } \\
\text {-decreases the proliferation rate } \\
\text {-supports macrophage adhesion } \\
\text { but does not allow fusion }\end{array}$ & [90] \\
\hline $\mathrm{Ti}_{50} \mathrm{Zr}(\mathrm{at} . \%)$ & $\begin{array}{c}\text { Polishing } \rightarrow \text { treatment in } 10 \mathrm{M} \\
\text { NaOH solution at } 60^{\circ} \mathrm{C}(24 \mathrm{~h}) \rightarrow \\
\text { heat treatment at } 600^{\circ} \mathrm{C}(1 \mathrm{~h})(\mathrm{a}) \\
\text { Polishing } \rightarrow \text { hydrothermal } \\
\text { deposition in a supersaturated } \\
\text { solution of } \mathrm{Ca}(\mathrm{OH})_{2} \text { at } 200^{\circ} \mathrm{C}(8 \mathrm{~h}) \\
\text { (b) }\end{array}$ & $\begin{array}{c}\mathrm{TiO}_{2} \\
\mathrm{ZrO}_{2} \\
\mathrm{Na}_{2} \mathrm{Ti}_{5} \mathrm{O}_{11} \\
\mathrm{Na}_{2} \mathrm{ZrO}_{3} \\
\mathrm{TiO}_{2} \\
\mathrm{ZrO}_{2} \\
\mathrm{CaTiO}_{3} \\
\mathrm{CaZrO}_{3}\end{array}$ & $\begin{array}{l}\mathrm{R}_{\mathrm{a}}-0.62 \mu \mathrm{m} ; \mathrm{R}_{\mathrm{s}}-3.02 \mu \mathrm{m} \\
\mathrm{R}_{\mathrm{a}}-0.60 \mu \mathrm{m} ; \mathrm{R}_{\mathrm{s}}-2.70 \mu \mathrm{m}\end{array}$ & $\begin{array}{l}\text { Porous network } \\
\text {-pore size: } 0.4-1.0 \mathrm{um} \\
\text {-layer thickness: } 12 \mu \mathrm{m} \\
\text { Porous network } \\
\text {-pore size: } 50-100 \mathrm{~nm} \\
\text {-layer thickness: } 45 \mathrm{~nm}\end{array}$ & $\begin{array}{c}\text { In simulated body fluid (SBF), } \\
\text { the formation of a compact layer } \\
\text { of apatite was observed in the } \\
\text { case of treated surfaces. } \\
\text { SaOS2: } \\
\text {-surface treatment has improved } \\
\text { cell adhesion and proliferation } \\
\text {-Ca }(\mathrm{OH})_{2} \text { treatment proved to } \\
\text { be a more effective treatment for } \\
\text { initial cell growth }\end{array}$ & [91] \\
\hline $\mathrm{Ti}_{50} \mathrm{Zr}$ (at.\%) & $\begin{array}{l}\text { Polishing } \rightarrow \text { Preparation of } \\
\text { colloidal solutions } \mathrm{TiO}_{2} \text { and } \mathrm{HAp} \\
\rightarrow \text { heating to } 80^{\circ} \mathrm{C}(2 \mathrm{~h}) \rightarrow \text { spin } \\
\text { coating } \rightarrow 6000^{\circ} \mathrm{C} \text { heat treatment }\end{array}$ & $\begin{array}{c}\mathrm{TiO}_{2} \\
\mathrm{CaTiO}_{3} \\
\mathrm{Ca}_{2} \mathrm{Ti}_{2} \mathrm{O}_{5}\end{array}$ & - & $\begin{array}{l}\text { Dense, uniform surface, without } \\
\text { cracks. } \\
\text { Layer thickness: } 50 \mu \mathrm{m}\left(\mathrm{TiO}_{2}(25\right. \\
\mu \mathrm{m}) \text { and } \mathrm{HAp}(25 \mu \mathrm{m}))\end{array}$ & $\begin{array}{l}\text { In } \mathrm{SBF} \text {, the formation of an } \\
\text { apatite layer was observed that } \\
\text { increased in thickness with time. }\end{array}$ & [92] \\
\hline $\mathrm{Ti}_{50} \mathrm{Zr}$ & $\begin{array}{l}\text { Polishing } \rightarrow \text { acid etching in a } \\
\text { mixture } 3: 730 \mathrm{wt} . \% \mathrm{H}_{2} \mathrm{O}_{2}: \\
98 \mathrm{wt} . \% \mathrm{H}_{2} \mathrm{SO}_{4}(1.5 \mathrm{~h}) \rightarrow \\
\text { dip-coating in poly(lactic acid) } \\
\text { solution } \rightarrow \text { electrospinning using } \\
\text { polycaprolactone solution with } \\
\text { dissolved silver nitrate } \rightarrow \\
\text { immersion in } 1 \mathrm{M} \mathrm{NaOH}(2 \mathrm{~h})\end{array}$ & - & $\begin{array}{l}\text { Contact angle: } 52.45^{\circ} \\
\text { Adhesion strength: } 2.7 \mathrm{MPa}\end{array}$ & $\begin{array}{l}\text { Fibers with a size between } 180-700 \\
\mathrm{~nm} \text { and silver nanoparticles of } \\
\qquad 30-40 \mathrm{~nm}\end{array}$ & $\begin{array}{l}\text { Microbial inhibition: } \\
\text { Escherichia coli (E. coli): } 74.27 \% \\
\text { S. aureus: } 66.02 \%\end{array}$ & [93] \\
\hline
\end{tabular}


Table 4. Cont.

\begin{tabular}{|c|c|c|c|c|c|c|}
\hline Alloy Type & Method & Morphology & Properties & Surface Topography & Biological Aspects & $\begin{array}{l}\text { Bibliographical } \\
\text { References }\end{array}$ \\
\hline $\mathrm{Ti}_{50} \mathrm{Zr}$ & $\begin{array}{c}\text { Polishing } \rightarrow \text { high voltage anodic } \\
\text { plasma deposition using Ag-C as } \\
\text { anode }\end{array}$ & $\begin{array}{c}\mathrm{ZrO}_{2} \\
\mathrm{TiO}_{2} \\
\mathrm{C} \\
\mathrm{Ag}\end{array}$ & $\begin{array}{c}\text { Contact angle: } \\
75.85^{\circ}-108.79^{\circ} \text { (increases } \\
\text { with } \mathrm{Ag} \text { content) } \\
\text { Roughness: } 0.8-3.58 \mathrm{~nm} \\
\text { (increases with } \mathrm{Ag} \text { content) }\end{array}$ & $\begin{array}{l}\text { Diamond like carbon film formed on } \\
\text { the natural layer of oxides with } \\
\text { silver nanoparticles in the form of } \\
\text { clusters of } 200-400 \mathrm{~nm} \\
\text { Layer thickness: } 39-720 \mathrm{~nm}\end{array}$ & - & [8] \\
\hline $\mathrm{Ti}_{50} \mathrm{Zr}$ & $\begin{array}{c}\text { Polishing } \rightarrow \text { immersion in } 10 \mathrm{M} \\
\mathrm{NaOH}\left(1 \mathrm{~h}, 60^{\circ} \mathrm{C}\right) \rightarrow \text { immersion } \\
\text { in } 3 \% 3 \text {-aminopropyl } \\
\text { triethoxysilane }(1 \mathrm{~h} \text {, room } \\
\text { temperature })-30 \mathrm{~min} \text { at } 80^{\circ} \mathrm{C} \rightarrow \\
\text { immersion in } 6 \mathrm{mg} / \mathrm{mL} \\
\text { 3-maleimidopropionic acid } \\
\text { N-hydroxysuccinimide ester } \\
(1.5 \mathrm{~h} \text {, room temperature }) \rightarrow \\
\text { immersion in } 2 \mathrm{mM} \text { L-cysteine } \\
(2 \mathrm{~h})\end{array}$ & - & Contact angle: $42.28^{\circ}$ & $\begin{array}{l}\text { Formation of a hydration layer with } \\
\text { a mean thickness of } 50 \mathrm{~nm}\end{array}$ & $\begin{array}{c}\text { Gingival fibroblasts: } \\
\text {-good biocompatibility } \\
\text {-no cytotoxicity was observed } \\
\text { Microbial inhibition: } \\
\text { E. coli: } 63.90 \% \\
\text { S. aureus: } 56.74 \%\end{array}$ & [94] \\
\hline $\mathrm{Ti}_{50} \mathrm{Zr}$ & $\begin{array}{c}\text { Polishing } \rightarrow \text { acid etching in } 12 \mathrm{M} \\
\mathrm{HCl}\left(1 \mathrm{~h}, 80^{\circ} \mathrm{C}\right) \rightarrow \\
\text { electrodeposition in } \mathrm{HAp} \text {-CS } \\
\text { solution at }-1500 \mathrm{mV}(1.5 \mathrm{~h} \text {, } \\
\left.90^{\circ} \mathrm{C}\right)\end{array}$ & - & $\begin{array}{l}\text { Contact angle: } 42^{\circ}-50^{\circ} \\
\text { (depending on the ratio of } \\
\text { HAp: CS) }\end{array}$ & $\begin{array}{c}\text { A uniform layer of HAp: CS was } \\
\text { observed. }\end{array}$ & - & [95] \\
\hline
\end{tabular}




\subsubsection{Surface Chemistry}

Even biomaterials such as $\mathrm{Ti}_{x} \mathrm{Zr}$, considered "inert", degrade to some extent over time, resulting in increased concentrations of metal ions. The release of metal ions from the implant takes place through the dissolution of the passive layer, mechanical wear and electrochemical corrosion. Metal ions can exist as such, but also in organometallic complexes, metal oxides or even nanoparticles [96]. Zirconium is considered an anodic alloying element for $\mathrm{Ti}$, which reduces anodic activity [97].

Implant corrosion leads to a decrease in their resistance and the release of metal ions in the surrounding tissues [98]. Valve metals, which develop a layer of oxide on the surface through exposure to air, have good corrosion resistance $[30,99]$. If the oxide layer is affected, the metal ions are released continuously until repassivation takes place [30].

Despite the fact that the passive layer functions as a physical barrier responsible for corrosion resistance that significantly hinders the release of metal ions into the surrounding tissues, small amounts of metal ions are still released from the metallic material. This process is a part of transient breakdown and reforming events of this film and to metal debris with acidification as a detriment to the stability of the passive regime. The breakdown of the titanium oxide layer by nucleation of corrosion pits occurs in bioliquids such as Ringer's solution at electrode potentials, well below the pitting potential. The frequency of breakdown increases significantly with $\mathrm{pH}$ value decrease, with temperature increase and in particular in the presence of chloride anions [100-103].

A study evaluating the corrosion resistance of $\mathrm{Ti}_{1}, \mathrm{Ti}_{x} \mathrm{Zr}(x=30,50,70 \%)$ and $\mathrm{Zr}$ in a lactic acid $+\mathrm{NaCl}$ solution and artificial saliva solution shows that the addition of $\mathrm{Zr}$ significantly increases the corrosion resistance, but up to a maximum content of 50\% [50].

Although the oxide layer forms naturally on the surface of $\mathrm{Ti}_{x} \mathrm{Zr}$ alloys, it is thin and weak. To improve $\mathrm{Zr}_{20} \mathrm{Ti}$ and $\mathrm{Zr}_{40} \mathrm{Ti}$ implants, oxidation at temperature $\left(500{ }^{\circ} \mathrm{C}, 2 \mathrm{~h}\right)$ was proposed, which led to the formation of an oxide layer of $\mathrm{ZrO}_{2}$ and $\mathrm{ZrTiO}_{4}$ with a thickness of 11-14 $\mu \mathrm{m}$. The oxide layer formed had both increased corrosion resistance and better wear resistance, the wear rate being almost 10 times lower in the case of $\mathrm{Zr20Ti}$ and almost 20 times in the case of $\mathrm{Zr}_{40} \mathrm{Ti}$ [18].

Regarding the electrochemical stability of $\mathrm{Ti}_{x} \mathrm{Zr}$ implants, it was observed that the presence of fluoride anions can have a negative impact, favoring corrosion. Given that these implants are frequently used as dental implants and that fluoride is introduced into toothpaste and mouthwash to prevent cavities, solutions must be found. It has been observed that the oxide film reacts with these anions, resulting in titanium fluoride or sodium titanium fluoride. The thermal oxidation of $\mathrm{Ti}_{x} \mathrm{Zr}$ alloys in air at $500{ }^{\circ} \mathrm{C}$ for two hours appears to significantly reduce the effect of fluoride [104] (pp. 7-8). Another study regarding the corrosion resistance of $\mathrm{Zr}-\mathrm{Ti}$ alloys shows too that the thermal oxidation in air at $500{ }^{\circ} \mathrm{C}$ does improve the corrosion resistance and suggests that prior to the use of such alloys as implant materials, a treatment consisting of thermal oxidation in air followed by exposure to a physiological solution should be applied [105].

The fluoride effect was tested on $\mathrm{Zr}_{5} \mathrm{Ti}, \mathrm{Zr}_{25} \mathrm{Ti}$ and $\mathrm{Zr}_{45} \mathrm{Ti}$ alloys in acidic artificial saliva, $\mathrm{Ph}=3$ with a NaF concentration of $0.2 \mathrm{wt} . \%, 0.5 \mathrm{wt} . \%$ and $1 \mathrm{wt} . \%$. The alloys were tested as such and after thermal oxidation in air at $500{ }^{\circ} \mathrm{C}$ for two hours. The results showed that although acidic artificial saliva with fluoride is a very aggressive medium for $\mathrm{Zr}_{x} \mathrm{Ti}$ alloys, thermal oxidation is an effective method of surface treatment. The oxide layers formed by $\mathrm{TiO}_{2}$ and $\mathrm{ZrO}_{2}$ provided a good corrosion resistance [106].

Another study performed on $\mathrm{Zr}_{5} \mathrm{Ti}_{1}, \mathrm{Zr}_{25} \mathrm{Ti}$ and $\mathrm{Zr}_{45} \mathrm{Ti}$ in artificial saliva solution, in the presence of $\mathrm{NaF}(0.05 \mathrm{wt} . \%, 0.1 \mathrm{wt} . \%$ and $0.2 \mathrm{wt} . \%)$ and albumin $(0.6 \mathrm{wt} . \%)$ showed that Zr45Ti has better corrosion resistance [107]. The same alloys were tested in Ringer's solution $(\mathrm{pH}=6.8)[108]$ and physiologically acidified Ringer's solution at $\mathrm{pH}=3$, also evidencing that $\mathrm{Zr}_{45} \mathrm{Ti}$ has the highest corrosion resistance. Moreover, it was observed that after thermal oxidation at $500{ }^{\circ} \mathrm{C}$, the oxide layers became thicker and more stable [81]. The higher Ti content (45\%) seems to lead to the suppression of pitting corrosion [109]. 
The evaluation of the oxide layer and its corrosion resistance on $\mathrm{Ti}_{20} \mathrm{Zr}$ alloy showed that the passivation takes place more easily and that the oxide layer has better corrosion resistance in Ringer's solution at acidic, neutral and alkaline $\mathrm{pH}$ compared to Ti. It was also observed that at acidic $\mathrm{pH}$, calcium and phosphate ions were deposited on the surface, and at neutral and alkaline $\mathrm{pH}$ a protective layer of hydroxyapatite (HAp) was formed [110].

The surface degradation of commercial $\mathrm{Ti}, \mathrm{Zr}$, and $\mathrm{ZrO}_{2}$ caused by bacterial adhesion (in particular, the Streptococcus species) has been discussed in several papers in the literature [111-113] concluding more recently that dental implant surfaces of TiZr and $\mathrm{ZrO}_{2}$ are not more susceptible to colonization than commercially pure Ti implants [114,115].

In addition to surface composition, the internal characteristics of metallic biomaterials, such as allotropic phase and defects, also influence the initiation and propagation of corrosion [116].

\subsubsection{Surface Topography}

Comparing the results reported on the surface roughness of biomaterials is difficult to achieve because there are variations regarding the analytical techniques and how the results are reported. Moreover, the terminology used is not harmonized and the same terms may refer to different procedures. However, it is generally accepted that surfaces with higher roughness favor osseointegration compared to smoother ones $[117,118]$.

In addition to the modification techniques, which determine the properties of the created surfaces, the methods of investigating them are also of major importance. Techniques such as nanoindenting and scratching techniques are used to characterize submicrometric surfaces. Nanoindentation allows for the evaluation of hardness and Young's modulus. The scratch test allows for the evaluation of coating adhesion to the substrate $[19,66]$.

Rough surfaces can be differentiated into two categories: modified surfaces by coating (e.g., HAp) or without coating (e.g., sandblasting, acid etching). Electrochemical changes, such as anodic oxidation or $\mathrm{NaOH}$ treatment lead to the formation of biomimetic surfaces by promoting the formation of apatite [119].

Obtaining structured surfaces on a micrometric scale is generally carried out by acid etching, sandblasting (SB) or oxidation. Sandblasting involves the use of abrasive particles $\left(\mathrm{Al}_{2} \mathrm{O}_{3}, \mathrm{TiO}_{2}, \mathrm{SiO}_{2}\right)$ at high pressure. This technique can lead to the incorporation of the particles used in the material and thus to the modification of chemical properties and reduced corrosion resistance. To solve this problem, a subsequent acid etching step is generally used to dissolve at least some of the projected particles. Acid etching produces similar results to sandblasting. The results obtained vary depending on the exposure time, type of acids used and temperature [117].

There is a $\mathrm{Ti}_{x} \mathrm{Zr}$ alloy marketed under the name Roxolid-SLA ${ }^{\circledR}$ (Straumann, Basel, Switzerland) $[11,13,120-123]$. This alloy contains $13-17 \%$ zirconium and is beginning to be considered the first choice in medical procedures [124]. The smaller grains of 1-2 $\mu \mathrm{m}$, compared to $20-30 \mu \mathrm{m}$ in cpTi lead to increased overall strength [125]. Another variant also produced by Straumann is RXD-SLActive ${ }^{\circledR}$ this implant is hydrophilic and has a nanostructured surface compared to Roxolid-SLA ${ }^{\circledR}$ [126].

The surface named SLA ${ }^{\circledR}$ is obtained by sandblasting with corundum (particle size 250-500 $\mu \mathrm{m}$ ) followed by etching with a concentrated mixture of hydrochloric acid and sulfuric acid. The implant is then cleaned with nitric acid, rinsed with deionized water and dried in an ambient atmosphere. For the SLActive ${ }^{\circledR}$ surface, the difference lies in rinsing with an $\mathrm{NaCl}$ solution in a nitrogen atmosphere and storage in $0.15 \mathrm{M}$ saline solution. This change, apparently minor, leads to a hydrophilic surface with better properties in terms of osseointegration. The formation of nanostructures was also observed on the SLActive ${ }^{\circledR}$ surface [127].

To highlight the differences between mechanical processing and acid etching, the properties of $\operatorname{Ti}_{x} \mathrm{Zr}$ alloys $(x=5,10,15 \mathrm{wt} . \%)$ with these two types of surface treatments were evaluated. The mechanically prepared samples were polished with an automatic polisher, and the etched ones were immersed in a mixture of sulfuric and hydrochloric acid 
for $1 \mathrm{~h}$ and $50 \mathrm{~min}$. Acid etching treatment produced a rougher surface and better overall properties [82].

The comparative study of the surface $\mathrm{Ti}, \mathrm{Ti}_{x} \mathrm{Zr}$ after sandblasting and acid etching respectively, showed that in the case of $\mathrm{Ti}_{x} \mathrm{Zr}$, the hydrogen concentration is 1.9 times higher. The formation of hydrides favored by the presence of $\mathrm{Zr}$ increases the roughness by the appearance of nanostructures, which in the case of the Ti surface was not observed. It was also observed that the hydride layer is below the oxide layer, which can be explained in the case of sandblasting-acid etching (SBAE) by the fact that the oxide layer is formed after the formation of hydride, but also by the fact that oxygen could replace hydrogen in the outer layer [128].

\subsection{Coatings with TiZr}

To obtain the advantages of $\mathrm{Ti}_{x} \mathrm{Zr}$ alloys, several studies have been developed that aimed to cover other substrates with these metals.

Through the plasma surface alloying technology, Zr ions were implanted in the surface of a Ti material, thus creating a $\mathrm{Ti}_{x} \mathrm{Zr}$ alloy only in the surface layer. The alloys thus created had a $\mathrm{Zr}$ content of 1.09 at.\%, 1.77 at.\% and 3.68 at.\%. The surface hardness and corrosion resistance proved to be better than that of cpTi. Good biocompatibility was also observed [17].

$\mathrm{A} \mathrm{Ti}_{x} \mathrm{Zr}$ surface was also obtained on $\mathrm{Ti}$ alloy by ion-assisted arc-plasma deposition in vacuum. The deposition was made by using two cathodes, one of $\mathrm{Ti}$ and one of $\mathrm{Zr}$, which were arc evaporated in Ar atmosphere, at $0.2 \mathrm{~Pa}$. The thickness of the obtained layer was $5 \mu \mathrm{m}$, with a $\mathrm{Zr}$ content of $11 \mathrm{wt} . \%$ and $22 \mathrm{wt} . \%$. The material thus obtained showed a low modulus of elasticity, of 77-98 GPa, compared with the Ti substrate which had 110 GPa. Moreover, nanoindentation showed an increase in resistance to plastic deformation with increasing $\mathrm{Zr}$ content from $11 \mathrm{wt} . \%$ to $22 \mathrm{wt}$ \% [129].

The use of a layer of $\mathrm{Ti}_{x} \mathrm{Zr}$ deposited on a steel material, SS304, also led to a significant improvement in corrosion resistance [130].

The explosive spraying of $\mathrm{Ti}-\mathrm{Zr}$ coating could help as well by reducing the Young's modulus of the materials used as substrate (cpTi or Ti6Al4V), therefore reducing stress shielding [131].

$\mathrm{Ti}-\mathrm{Zr}$ films were also deposited on Ti substrates by MAO, obtaining a porous crystalline layer of titanium and zirconium oxides. It has been observed that this approach leads to increased biocompatibility and that cell development increases proportionally with Zr content [132].

The incorporation of zirconium oxide into the oxide layer of Ti by plasma electrolytic oxidation (PEO) is another possible approach. A rougher surface was thus obtained, which by immersion in simulated body fluid (SBF) led to the formation of an apatite layer [133]. It was also shown that through this approach, the oxide layer formed favored osteoblast adhesion and could even decrease the bacterial adhesion [134]. Besides this, it was shown that nano-ZnO have antibacterial properties [135].

A possible coating that could lead to improved properties would be that with $\mathrm{ZrTiO}_{4}$ by the sol-gel method. The synthesis method has been developed but has not yet been applied to biomaterials [136].

\subsection{Nanostructured Coatings}

The design of nanometer-scale biomaterial surfaces is a subject of continuous research [137-140]. Nanostructured surfaces influence the chemical reactivity of materials and implicitly the biomolecular interactions [141,142]. It has been observed that nanoscale changes promote osteoinduction and biomaterial-tissue interaction and that implants with nanotubular surfaces show a significant improvement in bone creation and gene expression compared to implants without nanostructured surfaces [143-147]. 


\subsubsection{Nanotubes}

Anodizing may lead to self-ordered nanotubes, with certain dimensions (diameter, length) by varying the anodizing conditions. Nanostructures created in this way may have a partially crystalline structure. Their morphology influences electrochemical stability, wettability and biocompatibility [124].

The formation of nanotubes on TiZr substrate can be accomplished by a two-step anodizing procedure. They can be annealed in air or reduced in the atmosphere by $\mathrm{Ar} / \mathrm{H}_{2}$. By annealing, the mixed oxide tubes are converted to zirconium titanate $\left(\mathrm{ZrTiO}_{4}\right)$, and by reduction to $\left(\mathrm{Zr}_{0.333} \mathrm{Ti}_{0.666}\right) \mathrm{O}_{2}$ [124].

Nanotubes were reported to be obtained by two-step anodizing using an electrolyte solution with glycerin, $15 \%$ water and $0.2 \mathrm{M} \mathrm{NH}_{4}$ F. The first anodization was performed at $55 \mathrm{~V}$ for $4 \mathrm{~h}$, and then the samples were ultrasonicated to remove the formed structures. The second anodization was performed at $75 \mathrm{~V}$ for $1 \mathrm{~h}$. The formation of nanotubes is the result of a competition between the electrochemical formation of oxides and the chemical dissolution of oxides by the fluoride anion. Reactions can be described as follows [68]:

$$
\begin{gathered}
\mathrm{Me}+2 \mathrm{H}_{2} \mathrm{O} \rightarrow \mathrm{MeO}_{2}+4 \mathrm{H}^{+}+4 \mathrm{e}^{-} \\
\mathrm{MeO}_{2}+4 \mathrm{H}^{+}+6 \mathrm{~F}^{-} \rightarrow\left[\mathrm{MeF}_{6}\right]^{2-}+2 \mathrm{H}_{2} \mathrm{O}
\end{gathered}
$$

In the case of nanotubes formed on TiZr type alloys, the diameter of the nanotubes decreases with increasing $\mathrm{Zr}$ content. Nanotubes with a diameter of approximately $50 \mathrm{~nm}$ and a length of $17 \mathrm{~nm}$ were obtained. Regarding the heat treatment, fluorine can be removed at $300{ }^{\circ} \mathrm{C}$, and at $800^{\circ} \mathrm{C}$ crystallization occurs, but also the collapse of nanotubes [148].

The formation of $\mathrm{TiO}_{2}$ nanotubes by anodization at $10 \mathrm{~V}$ in $1.0 \mathrm{M}$ phosphoric acid and $0.5 \% \mathrm{NaF}$ for $2 \mathrm{~h}$ was also studied on $\mathrm{Ti}_{x} \mathrm{Zr}$ alloys $(x=10,20,30,40 \%)$. The nanotubes had an average diameter of 150-200 $\mathrm{nm}$ and a wall thickness of $20 \mathrm{~nm}$. The distance between the nanotubes increased with increasing $\mathrm{Zr}$ content of the alloy, being 60, 70, 100 and $130 \mathrm{~nm}[87]$.

Nanotubes were also obtained on $\mathrm{Ti}_{50} \mathrm{Zr}$ substrate by two-step anodizing at different voltages $(15,30,45 \mathrm{~V})$ in glycol with $15 \% \mathrm{H}_{2} \mathrm{O}$ and $0.2 \mathrm{M} \mathrm{NH}_{4} \mathrm{~F}$. The layer formed in the first anodization was removed by ultrasonic treatment, thus obtaining a prepared surface so that in the second stage of anodization nanotubular structures with a high degree of organization were obtained [149].

The zirconium titanate $\left(\mathrm{ZrTiO}_{4}\right)$ nanotubes formed on such alloys have increased structural flexibility compared to pure $\mathrm{TiO}_{2}$ nanotubes. The diameter and length of the formed tubes can vary depending on the anodizing potential used without damaging the structural configuration, at higher potentials the amorphous structure predominates over the crystalline one $[145,150]$. Another important aspect, less studied, is that nanotubes formed in this way can have an antibacterial role [150].

\subsubsection{Other Nanostructured Surfaces}

It was observed that nanopores were obtained on $\mathrm{Ti}_{50} \mathrm{Zr}$ by anodizing at $5 \mathrm{~V}$ and $10 \mathrm{~V}$ in a solution of $1 \mathrm{M}\left(\mathrm{NH}_{4}\right)_{2} \mathrm{SO}_{4}$ and $0.5 \mathrm{wt} \% \mathrm{NH}_{4} \mathrm{~F}$. The diameter of the nanopores was increasing with the applied potential. The material was subsequently annealed at $500{ }^{\circ} \mathrm{C}$ for three hours. The surfaces thus formed had an antibacterial effect, even if smaller than in the case of nanotubes [150].

The formation of nanopores was also observed by immersing an alloy of $\mathrm{Ti}_{50} \mathrm{Zr}$ with nanotubular surface obtained by two-step anodizing in a solution of $\mathrm{H}_{2} \mathrm{SO}_{4}(37 \mathrm{~N}) / \mathrm{H}_{2} \mathrm{O}_{2}$ $(30 \%)$ for two hours at room temperature [68] and when using spark anodization in a solution of glycerophosphate and calcium acetate on $\operatorname{Ti}_{x} \mathrm{Zr}(x=12-15 \mathrm{wt} . \%)$ [83].

The surface of a $\mathrm{Ti}_{20} \mathrm{Zr}$ alloy was galvanostatically anodized in phosphoric acid solution to increase the corrosion resistance. The current density was $10 \mathrm{~mA} / \mathrm{cm}^{2}$, the concentration of phosphoric acid was $1 \mathrm{M}$, and the anodizing time was $45 \mathrm{~min}$. It has been observed that this approach results in a nanometric layer consisting mostly of crystalline 
$\mathrm{TiO}_{2}$ with incorporated phosphorus ions. The corrosion resistance was 10 times higher in the case of the anodized sample [86].

Anodization in a hot solution of glycerol-phosphate of a $\mathrm{Ti}_{50} \mathrm{Zr}$ alloy led to onedimensional nanostructures in the form of channels $[90,151]$. As a result of this treatment, better corrosion resistance and higher hydrophilicity were obtained. Additionally, in vitro studies on RAW 264.7 macrophages showed a reduced reaction in the inflammatory response [90].

In a study on the cathodic polarization of some TiZr materials (13-17\% Zr) with a surface previously processed by sandblasting with aluminum oxide particles $(0.25-0.5 \mathrm{~mm})$, the acid etching treatment with a mixture of hydrochloric acid and sulfuric acid at $125-130{ }^{\circ} \mathrm{C}$ for 5 min produced nano-nodules [84].

Another type of nanostructured coating was made with two biopolymers, poly(lactic acid) and polycaprolactone. The methods used were dip coating and electrospinning, respectively, thus obtaining nanofibers [93].

\subsection{Biomimetic Coatings}

On a Ti15Zr alloy, obtained by mechanical processing (Straumann AG), a biofunctional coating was formed by PEO. As the control, the same unmodified alloy was used, and some were SLA ${ }^{\circledR}$-treated (sandblasting and acid etching). The samples were used as an anode, while the cathode was a steel tank equipped with a cooling system. The electrolyte solution contained calcium acetate and disodium glycerol phosphate. The samples were immersed in $500 \mathrm{~mL}$ of solution for $10 \mathrm{~min}$, using a voltage of $290 \mathrm{~V}$ and a frequency of $250 \mathrm{~Hz}$. During the electrochemical treatment, pores appeared in the places where the micro-discharge took place, thus obtaining molten oxides which were quickly cooled in the presence of electrolytes when the spark was extinguished. This phenomenon led to the incorporation of $\mathrm{Ca}$ and $\mathrm{P}$, resulting in a $\mathrm{Ca} / \mathrm{P}$ ratio close to that of HAp. This aspect combined with the increased surface roughness significantly influenced the biological properties of the implant. In terms of stability, the PEO-treated alloy showed the highest corrosion resistance compared to control ones [85].

Two other ways to modify the surface of a $\mathrm{Ti}_{50} \mathrm{Zr}$ at.\% alloy have been proposed. One of the methods involved immersing the sample in $10.0 \mathrm{M} \mathrm{NaOH}$ at $60^{\circ} \mathrm{C}$ for $24 \mathrm{~h}$. The samples were dried at room temperature in air for another $24 \mathrm{~h}$. They were then heat treated at $600{ }^{\circ} \mathrm{C}$ for one hour in an electric high vacuum furnace. The other method involved the hydrothermal storage in a supersaturated solution of $0.2 \mathrm{M}$ calcium hydroxide in an autoclave at $200{ }^{\circ} \mathrm{C}$ for eight hours. In the first case, a $12 \mu \mathrm{m}$ oxide layer composed of $\mathrm{TiO}_{2}, \mathrm{ZrO}_{2}, \mathrm{Na}_{2} \mathrm{Ti}_{5} \mathrm{O}_{11}$ and $\mathrm{Na}_{2} \mathrm{ZrO}_{3}$, and in the second case a $45 \mathrm{~nm}$ layer composed of $\mathrm{TiO}_{2}, \mathrm{ZrO}_{2}, \mathrm{CaTiO}_{3}$ and $\mathrm{CaZrO}_{3}$ was formed. When immersed in SBF, a layer of apatite was observed in the case of both treated surfaces, but not in the untreated ones [91].

In the case of alkaline treatment, the native layer partially dissolves in the alkaline solution, forming $\mathrm{HTiO}_{3}-\mathrm{H}_{2} \mathrm{O}$ anions, which combine with the cations to form a hydrogel layer. During the heat treatment, this layer is dehydrated resulting in an amorphous or crystalline form of alkali titanate [152].

The deposition of a $\mathrm{HAp} / \mathrm{TiO}_{2}$ layer on $\mathrm{TiZr}$ alloy has been reported by the sol-gel method at $3000 \mathrm{rpm}$ for $15 \mathrm{~s}$, followed by heat treatment at $600^{\circ} \mathrm{C}$ for $20 \mathrm{~min}$. Subsequent heat treatment at $600{ }^{\circ} \mathrm{C}$ for another $20 \mathrm{~min}$ resulted in HAp crystallization. The obtained layer had a total thickness of $50 \mu \mathrm{m}$, being formed in equal proportion of $\mathrm{TiO}_{2} / \mathrm{HAp}$ [92] Regardless of the sol-gel method used, cracks may occur due to contractions caused by the evaporation of a large volume of solvent [153]. In the case of $\mathrm{TiO}_{2}$ coating, the formed cracks were subsequently coated with HAp. The mechanism of apatite formation in SBF can be explained by the release of $\mathrm{Ca}^{2+}, \mathrm{Na}^{+}, \mathrm{K}^{+}$, ions from the HAp deposited layer and their exchange with hydronium ions from the SBF solution, forming $\mathrm{Ti}-\mathrm{OH}, \mathrm{Zr}-\mathrm{OH}$ groups. These functional groups can react with water molecules in the environment by inducing nucleation. Once formed, apatite nuclei can grow spontaneously by consuming ions from the SBF solution [92]. 
The coating of TiZr with HAp was also performed in combination with chitosan (CS), obtaining coatings with different porosities and contact angles depending on the HAp/CS ratio used $[20,95,154]$.

Another type of biomimetic coating used on $\mathrm{Ti}_{x} \mathrm{Zr}$ type alloys $\left(\mathrm{Ti}_{5} \mathrm{Zr}, \mathrm{Ti}_{25} \mathrm{Zr}\right.$ and $\mathrm{Ti}_{45} \mathrm{Zr}$ ) can be the coating with $\mathrm{HAp}-\mathrm{ZrO}_{2}-\mathrm{Ag}$, which favors the formation of bone tissue $[88,155]$. Silver nanoparticles (AgNPs) are effective, in very low concentrations $(0.5-1.0 \%)$, in preventing the formation of bacterial biofilm. They interact with proteoglycans on the membrane of bacterial cells and inside them. Silver ions can also interact with sulfuryl groups preventing the replication of bacterial DNA [156-158].

Moreover, the development of bioinductive surfaces could increase the healing capacity of bone tissue and is a solution for patients with risk factors $[70,159]$. The implantation of a biologically active molecule (parathyroid hormone fragment 1-34) in the natural oxide layer was performed on a TiZr implant (Straumann AG) [70].

\subsection{Biological Aspects}

The interactions between cells and biomaterial are determined by the surface properties $[160,161]$. Cells do not interact directly with the surface of the biomaterial, but with the protein layer adsorbed on the surface. The transcriptomic and proteomic technologies used to create gene and protein expression profiling can be used for a more thorough understanding and to predict the biocompatibility of the researched materials [162-165].

The interaction between human gingival fibroblasts and $\mathrm{Ti}_{x} \mathrm{Zr}$ materials with surfaces treated in different ways shows that cell adhesion and differentiation are influenced by surface properties [166,167]. Another study that looked at the expression of several genes involved in the process of cell adhesion shows that high surface energy positively influences the adhesion of osteoblasts [168].

Microbial infections and in particular infections with multidrug resistant microbes are a major problem that must be considered in the development of all biomaterials [169-171]. Recent research focuses on the use of nanotechnology in solving this problem, nanometrically structured materials having characteristics far superior to conventional ones (bulk form). Additionally, the reactive oxygen species produced by the use of nanocomposite oxide metals or nanoparticles cause the inhibition of bacterial growth [170].

Bacterial adhesion can lead initially to mucositis and later to periimplantitis, which can cause implant loss. Thus this aspect is approached and studied in many studies [172-174]. Surface properties, such as roughness, free energy (wettability) and chemical composition are the determining factors in terms of cell adhesion and microbial colonization $[173,175,176]$.

Surface roughness, chemical composition, wettability and surface charge also influence the structure and size of the biofilm. Although it is a subject often studied, the results obtained in vitro may differ from those obtained in vivo. The differences appear because it is difficult to imitate the biologically complex environment. In vivo studies show that bacterial adhesion increases with increasing roughness and hydrophobic surfaces promote the accumulation of proteins, which serve as a binding site for bacteria [177].

In a time with more aggressive bacteria and viruses, for the success of dental implants, besides the incorporation of efficient antibacterial agents inside implants, loading of the antiinflammatory drugs to reduce inflammation and bone forming proteins/peptides/growth factors (bone morphogenetic protein-2/BMP-2, parathyroid hormone, $\mathrm{Zn} / \mathrm{Ag} / \mathrm{Sr} / \mathrm{Mg}$ ions/nanoparticles) to enhance new bone formation at the implant-bone interface have been applied [178-180]. More recently, creating composite structures with graphene and nanotubes on the implant surface proved to have efficient dual antibacterial and osteogenic properties [181].

Another important aspect is related to the tribocorrosion of metallic materials. The released metal nanoparticles (metal wear debris) can migrate to any part of the body (except the brain), depositing in the lymph nodes, the liver, spleen and bone marrow. They also have a genotoxic potential, which can affect the genetic material, which could lead to cancer or birth defects [182]. 
The dissolution of the oxide layers is relatively low in vitro because the potential changes are small, but in the body, this process can be accelerated by the presence of amino acids and proteins. Another process that can accelerate this phenomenon is the generation of reactive oxygen species by macrophages. Superoxide dismutase catalyzes $\mathrm{O}^{2-}$ producing $\mathrm{H}_{2} \mathrm{O}_{2}$ that hyperoxidize the surface of the material. The process that takes place simultaneously with the dissolution is the reprecipitation, the two being in equilibrium. Phosphate ions are adsorbed on the outer oxide layers of Ti alloys, and subsequently, calcium ions are adsorbed by them forming an apatite layer. In addition to these, proteins, sulfites and sulfates have also been observed $[183,184]$.

\subsubsection{The Influence of Surfaces In Vitro}

$\mathrm{Ti}_{x} \mathrm{Zr}$ alloys ( $x=5,10,15,20$ wt.\%) were studied, proving that they do not show cytotoxicity [185]. Moreover, compared to other commercial Ti-based alloys, cells on TiZr implants expressed a decrease in pro-inflammatory markers and an increase in antiinflammatory markers, especially in the case of nanostructured alloy [126].

The formation of nanotubes, mechanical properties and inhibition of bacterial growth of $S$. aureus was studied on pure $\mathrm{Ti}$ and $\mathrm{Zr}$ alloys, as well as on several $\mathrm{Ti}_{x} \mathrm{Zr}$ binary alloys $(x=10,30,50,70$ at.\%), noting that nanotubular formations inhibit bacterial growth [89]. In the case of $\mathrm{TiO}_{2}$ nanotubes, it has been observed that annealing can increase the inhibitory effect on S. aureus and Pseudomonas aeruginosa and even that it increases depending on the temperature used [186].

The properties of nanotubes formed on $\mathrm{Ti}_{50} \mathrm{Zr}$ by two-step anodizing were also evaluated, in vitro, on E. coli culture. It was observed that the antibacterial efficacy depends on the diameter of the tubes formed, a size that can be controlled by the potential used for anodizing. Tubes with a diameter of less than 20-30 nm demonstrated a better bacteriostatic and bactericidal effect than those with a larger diameter of 50-70 nm [187].

Nanotubes can also be loaded with therapeutic agents, either as such or embedded in a polymer, by electrospray, lyophilization, immersion or vacuum impregnation techniques [188]. On a $\mathrm{Ti}_{50} \mathrm{Zr}$ alloy two types of nanostructures were formed, nanopores and nanotubes, that were loaded with gentamicin and coated with a layer of CS. It was observed that gentamicin was released from nanopores in 10 days, and from nanotubes in 21 days [68].

Another coating with a zwitterionic cysteine drug was investigated recently, reporting better performance in terms of stability, biocompatibility and antibacterial effect. The obtained structure evidenced large bands due to hydroxylic groups which formed a hydration layer and determined the increase in hydrophilic character. This layer was responsible for an antibacterial effect as well. The electrochemical tests performed in $\mathrm{NaCl} 0.9 \%$ as bioliquid confirmed the improved stability of the coated sample. The cell behavior in the presence of cysteine coating was determined with gingival fibroblasts, by measuring lactate dehydrogenase activity, concentrations of nitric oxide and the level of reactive oxygen species. The results obtained indicated that the coating is biocompatible, and no cytotoxicity was evidenced [94].

The cell morphology of MG63 cells (osteoblast-like cells) on $\mathrm{Ti}_{50} \mathrm{Zr}$ with a nanostructured surface also showed good biocompatibility [149], while the studies performed on RAW 264.7 macrophages showed a reduced reaction in inflammatory response in the case of unidimensional nanochannels [90].

The incorporation of $\mathrm{Ag}$ into $\mathrm{Ti}_{50} \mathrm{Zr}$ showed strong antibacterial activity on S. aureus [189] and coating a $\mathrm{Ti}_{50} \mathrm{Zr}$ alloy with poly (lactic acid), polycaprolactone and silver nanoparticles showed good inhibitory activity in E. coli and S. aureus [93].

Amorphous biomaterials such as $\mathrm{Zr}_{46} \mathrm{Ti}_{40} \mathrm{Ag}_{14}$ have been studied too as an alternative to conventional crystalline ones [189]. They do not have structural deficiencies characteristic of crystalline structures (dislocation, vacancy, twinning, grain boundary), which can lead to better mechanical properties and increased corrosion resistance, as well as antibacterial properties due to the Ag [190]. 
In the case of surfaces treated in alkaline solution, and subsequently, heat treated, better cell adhesion and proliferation were observed for $\mathrm{SaOS}_{2}$ [91]. Coating a Ti-based alloy with $\mathrm{CaTiZr}_{3}\left(\mathrm{PO}_{4}\right)_{6}$ also showed that the coating promoted cell proliferation and bone formation [191].

\subsubsection{The Influence of Surfaces In Vivo}

$\mathrm{Ti}_{x} \mathrm{Zr}$ implants $(x=13-17 \%)$ prepared by sandblasting and acid etching evaluated for 12 weeks in a study in rabbits show biocompatibility as good as in the case of cpTi [192]. In another study on titanium-zirconium (SLActive surface treatment) implants in rabbits, an increased quality was shown regarding bone formation in the case of TiZr compared with Ti. The evaluation was carried out through the removal of torque values [193].

Additonally, a better response in the case of SLActive ${ }^{\circledR}$ (nanostructured surface) highlighted in a study on human bone mesenchymal stem cells (hBMSCs) [194] is confirmed by a retrospective evaluation in another study of 154 Roxolid implants with SLActive ${ }^{\circledR}$ in 107 patients that showed high survival rates [122]. TiZr implant alloys, in general, proved positive outcomes in numerous studies [120,121,123,195-197]. Despite the success rate of dental TiZr implants, avoiding the acute surgical site infections in some patients is still challenging [198] due to several unsuccessful events [199] and researchers suggested coating therapeutic drugs on the biomaterials surface to locally release antibiotics in a controlled manner [200].

By using a cathodic polarization setup, a doxycycline loading of a TiZr alloy with a Zr content of 13-17\% was performed. The method of preparation of the sample was that used for the preparation of Roxolid SLActive ${ }^{\circledR}$, namely grit blasted and etching in sulfuric and hydrochloric acid. Samples were handled in a nitrogen atmosphere and stored in $0.9 \% \mathrm{NaCl}$. The coating was made by connecting the samples to the cathode, the anode being Pt. A constant current of $0.65 \mathrm{~mA}$ was used for each sample. The electrolyte was a $2 \mathrm{M}$ acetate buffer solution in which doxycycline was dissolved to obtain $1 \mathrm{mg} / \mathrm{mL}$. The process took $75 \mathrm{~min}$ and was performed at room temperature. The samples were further dried and stored in a nitrogen atmosphere. The coated surface evaluated in a rabbit tibial model showed increased markers related to bone formation [201].

Following the idea that coating implantable metal alloys with active substances could be a solution for controlling inflammation and post-interventional infections, the use of a doxycycline-coated $\mathrm{Ti}_{x} \mathrm{Zr}$ alloy compared to the same doxycycline-free alloy was studied as well in dogs and rabbits. The coating did not produce different histological and histomorphometrical results compared to the control group [200].

Three binary TiZr alloys $\left(\mathrm{Ti}_{5} \mathrm{Zr}, \mathrm{Ti}_{25} \mathrm{Zr}\right.$ and $\mathrm{Ti}_{45} \mathrm{Zr}$ ) coated with a layer of $\mathrm{HAp}-\mathrm{ZrO}_{2}-$ Ag were tested after implantation in pig tibia. It was observed that osseointegration was influenced both by the interaction between the tissue and the coating and by the chemical composition of the bulk alloy. The $\mathrm{Ti}_{45} \mathrm{Zr}$ alloy showed a better organizational structure of newly formed bone tissue, as well as increased proliferation and differentiation of osteoblasts [88].

Another in vivo study in mice shows that Ti materials with a nanostructured coating of $\mathrm{TiO}_{2}$ or $\mathrm{ZrO}_{2}$ have a positive influence on cell differentiation [202], while another study performed on sheep shows that the anodizing of both $\mathrm{Ti}$ and $\mathrm{Ti}_{x} \mathrm{Zr}(x=12-15 \mathrm{wt} . \%)$ improves osseointegration [203].

\section{Conclusions}

The critical approach decided upon in this review has led to the clear conclusion that $\mathrm{Ti}_{x} \mathrm{Zr}$ alloys have all the characteristics of a good biomaterial. Not only do they exhibit great biocompatibility, but the mechanical properties are improved up to 2.5 times in $\mathrm{Ti}_{50} \mathrm{Zr}$ compared to $\mathrm{Ti}$ or $\mathrm{Zr}$. Moreover, the surface modification methods described in the reviewed studies suggest that with the right combination of chemical and instrumental techniques, many characteristics and properties can be molded. 
The alloys are naturally protected against corrosion through a layer of oxides, that can be easily further improved through thermal oxidation. More complex methods such as anodizing or sol-gel coatings can be used to obtain different nanostructures that improve cellular interaction, being similar in size. Of course, the risk of bacterial biofilm formation increases too, but besides the antibacterial effect of some of the nanostructures, antibiotic substances or other nanoparticles that inhibit bacterial growth may be used in the coating as well. Furthermore, coatings with hydroxyapatite can improve cell differentiation and proliferation. Additionally, all the studies performed in vivo, that we know of, showed promising results.

Taking into consideration all the above-mentioned aspects, we believe that TiZr may become one of the most used metallic biomaterials in the future.

Author Contributions: Conceptualization, D.I. and I.D.; investigation, R.N., D.I., and I.D.; data curation, R.N., D.I., and I.D.; writing—original draft preparation, R.N., D.I., and I.D.; writing—review and editing, D.I., and I.D.; visualization, R.N.; supervision, I.D. All authors have read and agreed to the published version of the manuscript.

Funding: This research received no external funding.

Institutional Review Board Statement: Not applicable.

Informed Consent Statement: Not applicable.

Data Availability Statement: Data sharing not available.

Conflicts of Interest: The authors declare no conflict of interest

\section{References}

1. Iftikhar, S.; Jahanzeb, N.; Saleem, M.; Rehman, S.; Matinlinna, J.P.; Khan, A.S. The trends of dental biomaterials research and future directions: A mapping review. Saudi Dent. J. 2021. [CrossRef]

2. Ho, W.-F.; Chen, W.-K.; Wu, S.-C.; Hsu, H.-C. Structure, mechanical properties, and grindability of dental Ti-Zr alloys. J. Mater. Sci. Mater. Med. 2008, 19, 3179-3186. [CrossRef]

3. He, X.; Reichl, F.X.; Milz, S.; Michalke, B.; Wu, X.; Sprecher, C.M.; Yang, Y.; Gahlert, M.; Röhling, S.; Kniha, H.; et al. Titanium and zirconium release from titanium-and zirconia implants in mini pig maxillae and their toxicity in vitro. Dent. Mater. 2020, 36, 402-412. [CrossRef] [PubMed]

4. Li, J.; Jansen, J.A.; Walboomers, X.F.; van den Beucken, J.J. Mechanical aspects of dental implants and osseointegration: A narrative review. J. Mech. Behav. Biomed. Mater. 2020, 103, 103574. [CrossRef]

5. Osman, R.B.; Swain, M.V. A critical review of dental implant materials with an emphasis on titanium versus zirconia. Materials 2015, 8, 932-958. [CrossRef]

6. Shekhawat, D.; Singh, A.; Banerjee, M.K.; Singh, T.; Patnaik, A. Bioceramic composites for orthopaedic applications: A comprehensive review of mechanical, biological, and microstructural properties. Ceram. Int. 2021, 47, 3013-3030. [CrossRef]

7. Ionita, D.; Bajenaru-Georgescu, D.; Totea, G.; Mazare, A.; Schmuki, P.; Demetrescu, I. Activity of vancomycin release from bioinspired coatings of hydroxyapatite or TiO2 nanotubes. Int. J. Pharm. 2017, 517, 296-302. [CrossRef]

8. Stoian, A.B.; Surdu-Bob, C.; Anghel, A.; Ionita, D.; Demetrescu, I. Investigation of High Voltage Anodic Plasma (HVAP) Ag-DLC Coatings on $\mathrm{Ti}_{50} \mathrm{Zr}$ with Different Ag Amounts. Coatings 2019, 9, 792. [CrossRef]

9. Mani, G.; Feldman, M.D.; Patel, D.; Agrawal, C.M. Coronary stents: A materials perspective. Biomaterials 2007, 28, 1689-1710. [CrossRef] [PubMed]

10. Jiang, J.; Zhou, C.; Zhao, Y.; He, F.; Wang, X. Development and properties of dental Ti-Zr binary alloys. J. Mech. Behav. Biomed. Mater. 2020, 112, 104048. [CrossRef]

11. Altuna, P.; Lucas-Taulé, E.; Gargallo-Albiol, J.; Figueras-Álvarez, O.; Hernández-Alfaro, F.; Nart, J. Clinical evidence on titaniumzirconium dental implants: A systematic review and meta-analysis. Int. J. Oral Maxillofac. Surg. 2016, 45, 842-850. [CrossRef]

12. Ionita, D.; Pirvu, C.; Stoian, A.B.; Demetrescu, I. The Trends of TiZr Alloy Research as a Viable Alternative for Ti and Ti16 Zr Roxolid Dental Implants. Coatings 2020, 10, 422. [CrossRef]

13. Sharma, A.; Waddell, J.N.; Li, K.C.; Sharma, L.A.; Prior, D.J.; Duncan, W.J. Is titanium-zirconium alloy a better alternative to pure titanium for oral implant? Composition, mechanical properties, and microstructure analysis. Saudi Dent. J. 2020, 4-11. [CrossRef]

14. Michelle Grandin, H.; Berner, S.; Dard, M. A review of Titanium Zirconium (TiZr) alloys for use in endosseous dental implants. Materials 2012, 5, 1348-1360. [CrossRef]

15. Kondoh, K.; Fukuo, M.; Kariya, S.; Shitara, K.; Li, S.; Alhazaa, A.; Umeda, J. Quantitative strengthening evaluation of powder metallurgy Ti-Zr binary alloys with high strength and ductility. J. Alloys Compd. 2021, 852, 156954. [CrossRef] 
16. Möller, B.; Terheyden, H.; Ail, Y.; Purcz, N.M.; Hertrampf, K.; Tabakov, A.; Behrens, E.; Wiltfang, J. A comparison of biocompatibility and osseointegration of ceramic and titanium implants: An in vivo and in vitro study. Int. J. Oral Maxillofac. Surg. 2012, 41, 638-645. [CrossRef] [PubMed]

17. Yan, B.; Tan, J.; Wang, D.; Qiu, J.; Liu, X. Surface alloyed Ti-Zr layer constructed on titanium by Zr ion implantation for improving physicochemical and osteogenic properties. Prog. Nat. Sci. Mater. Int. 2020, 30, 635-641. [CrossRef]

18. Cui, W.F.; Shao, C.J. The improved corrosion resistance and anti-wear performance of Zr-xTi alloys by thermal oxidation treatment. Surf. Coat. Technol. 2015, 283, 101-107. [CrossRef]

19. Vardaki, M.; Pantazi, A.; Demetrescu, I.; Enachescu, M. Assessing the Functional Properties of TiZr Nanotubular Structures for Biomedical Applications, through Nano-Scratch Tests and Adhesion Force Maps. Molecules 2021, 26, 900. [CrossRef]

20. Ionita, D.; Vardaki, M.; Stan, M.S.; Dinischiotu, A.; Demetrescu, I. Enhance Stability and in vitro Cell Response to a Bioinspired Coating on Zr Alloy with Increasing Chitosan Content. J. Bionic Eng. 2017, 14, 459-467. [CrossRef]

21. George, E.P.; Raabe, D.; Ritchie, R.O. High-entropy alloys. Nat. Rev. Mater. 2019, 4, 515-534. [CrossRef]

22. Wen, J.; Chu, X.; Cao, Y.; Li, N. Effects of Al on Precipitation Behavior of Ti-Nb-Ta-Zr Refractory High Entropy Alloys. Metals 2021, 11, 514. [CrossRef]

23. Soni, V.; Gwalani, B.; Alam, T.; Dasari, S.; Zheng, Y.; Senkov, O.N.; Miracle, D.; Banerjee, R. Phase inversion in a two-phase, BCC+B2, refractory high entropy alloy. Acta Mater. 2020, 185, 89-97. [CrossRef]

24. Todai, M.; Nagase, T.; Hori, T.; Matsugaki, A.; Sekita, A.; Nakano, T. Novel TiNbTaZrMo high-entropy alloys for metallic biomaterials. Scr. Mater. 2017, 129, 65-68. [CrossRef]

25. Ji, P.F.; Li, B.; Chen, B.H.; Wang, F.; Ma, W.; Zhang, X.Y.; Ma, M.Z.; Liu, R.P. Effect of Nb addition on the stability and biological corrosion resistance of Ti-Zr alloy passivation films. Corros. Sci. 2020, 170. [CrossRef]

26. Pitchi, C.S.; Priyadarshini, A.; Sana, G.; Narala, S.K.R. A review on alloy composition and synthesis of $\beta$-Titanium alloys for biomedical applications. Mater. Today Proc. 2020, 26, 3297-3304. [CrossRef]

27. Pintaõ, C.A.F.; Correa, D.R.N.; Grandini, C.R. Torsion modulus as a tool to evaluate the role of thermo-mechanical treatment and composition of dental Ti-Zr alloys. J. Mater. Res. Technol. 2019, 8, 4631-4641. [CrossRef]

28. Ji, P.; Chen, B.; Li, B.; Tang, Y.; Zhang, G.; Zhang, X.; Ma, M.; Liu, R. Influence of Nb addition on microstructural evolution and compression mechanical properties of Ti-Zr alloys. J. Mater. Sci. Technol. 2021, 69, 7-14. [CrossRef]

29. Wen, C.E.; Yamada, Y.; Hodgson, P.D. Fabrication of novel TiZr alloy foams for biomedical applications. Mater. Sci. Eng. C 2006, 26, 1439-1444. [CrossRef]

30. Kaur, M.; Singh, K. Review on titanium and titanium based alloys as biomaterials for orthopaedic applications. Mater. Sci. Eng. C 2019, 102, 844-862. [CrossRef]

31. Liu, Y.; Tang, H.; Huang, Q.; Zhao, D.; He, J.; Cao, Y.; Song, M.; Liu, B.; Ouyang, S. Strong-yet-ductile Ti-Zr alloys through high concentration of oxygen strengthening. Trans. Nonferrous Met. Soc. China 2020, 30, 2449-2458. [CrossRef]

32. Vicente, F.B.; Correa, D.R.N.; Donato, T.A.G.; Arana-Chavez, V.E.; Buzalaf, M.A.R.; Grandini, C.R. The influence of small quantities of oxygen in the structure, microstructure, hardness, elasticity modulus and cytocompatibility of Ti-Zr alloys for dental applications. Materials 2014, 7, 542-553. [CrossRef] [PubMed]

33. Biesiekierski, A.; Wang, J.; Abdel-Hady Gepreel, M.; Wen, C. A new look at biomedical Ti-based shape memory alloys. Acta Biomater. 2012, 8, 1661-1669. [CrossRef] [PubMed]

34. Correa, D.R.N.; Kuroda, P.A.B.; Lourenço, M.L.; Buzalaf, M.A.R.; Mendoza, M.E.; Archanjo, B.S.; Achete, C.A.; Rocha, L.A.; Grandini, C.R. Microstructure and selected mechanical properties of aged Ti-15Zr-based alloys for biomedical applications. Mater. Sci. Eng. C 2018, 91, 762-771. [CrossRef]

35. Correa, D.R.N.; Vicente, F.B.; Donato, T.A.G.; Arana-Chavez, V.E.; Buzalaf, M.A.R.; Grandini, C.R. The effect of the solute on the structure, selected mechanical properties, and biocompatibility of Ti-Zr system alloys for dental applications. Mater. Sci. Eng. C 2014, 34, 354-359. [CrossRef]

36. Sngfeng, E.; Shi, L.; Guo, Z.G.; Liu, W.M. The recent progress of tribological biomaterials. Biosurface Biotribol. 2015, 1, 81-97. [CrossRef]

37. Sarswat, P.K.; Sarkar, S.; Murali, A.; Huang, W.; Tan, W.; Free, M.L. Additive manufactured new hybrid high entropy alloys derived from the AlCoFeNiSmTiVZr system. Appl. Surf. Sci. 2019, 476, 242-258. [CrossRef]

38. Cao, Y.; Liu, Y.; Liu, B.; Zhang, W. Precipitation behavior during hot deformation of powder metallurgy Ti-Nb-Ta-Zr-Al high entropy alloys. Intermetallics 2018, 100, 95-103. [CrossRef]

39. Hsu, H.C.; Wu, S.C.; Sung, Y.C.; Ho, W.F. The structure and mechanical properties of as-cast Zr-Ti alloys. J. Alloys Compd. 2009, 488, 279-283. [CrossRef]

40. Niinomi, M.; Nakai, M.; Hieda, J. Development of new metallic alloys for biomedical applications. Acta Biomater. 2012, 8, 3888-3903. [CrossRef]

41. Rodríguez-Hernández, M.G.; Jiménez, O.; Alvarado-Hernández, F.; Flores, M.; Andrade, E.; Canto, C.E.; Ávila, C.; EspinozaBeltrán, F. The effect of $C$ content on the mechanical properties of Ti-Zr coatings. J. Mech. Behav. Biomed. Mater. 2015, 49, 269-276. [CrossRef]

42. Matuła, I.; Dercz, G.; Zubko, M.; Maszybrocka, J.; Jurek-Suliga, J.; Golba, S.; Jendrzejewska, I. Microstructure and porosity evolution of the ti-35zr biomedical alloy produced by elemental powder metallurgy. Materials 2020, 13, 4539. [CrossRef] 
43. Annur, D.; Kartika, I.; Supriadi, S.; Suharno, B. Titanium and titanium based alloy prepared by spark plasma sintering method for biomedical implant applications-A review. Mater. Res. Express 2021, 8. [CrossRef]

44. Nguyen, V.T.; Wong, X.P.C.; Song, S.M.; Tsai, P.H.; Jang, J.S.C.; Tsao, I.Y.; Lin, C.H.; Nguyen, V.C. Open-cell tizr-based bulk metallic glass scaffolds with excellent biocompatibility and suitable mechanical properties for biomedical application. J. Funct. Biomater. 2020, 11, 28. [CrossRef] [PubMed]

45. Rajan, S.T.; Thampi, V.V.A.; Terada-Nakaishi, M.; Chen, P.; Hanawa, T.; Nandakumar, A.K.; Subramanian, B. Zirconium-based metallic glass and zirconia coatings to inhibit bone formation on titanium. Biomed. Mater. 2020, 15. [CrossRef]

46. Hanawa, T. Zirconia versus titanium in dentistry: A review. Dent. Mater. J. 2020, 39, 24-36. [CrossRef] [PubMed]

47. Teffo, M.L.; Nyakane, N.E.; Seerane, M.; Shongwe, M.B.; Machaka, R. The effect of alloying elements on densification and mechanical behaviour of titanium based alloy. Mater. Today Proc. 2021, 38, 1203-1208. [CrossRef]

48. Jiang, J.; Zhao, Y.; Wang, X. Effects of Zr addition on the deformation behavior, microstructure and mechanical properties of dental Ti alloys. Mater. Sci. Eng. A 2020, 794, 139808. [CrossRef]

49. Ali, F.; Mehmood, M.; Qasim, A.M.; Ahmad, J.; Naeem-ur-Rehman; Iqbal, M.; Qureshi, A.H. Comparative study of the structure and corrosion behavior of $\mathrm{Zr}-20 \% \mathrm{Cr}$ and $\mathrm{Zr}-20 \%$ Ti alloy films deposited by multi-arc ion plating technique. Thin Solid Films 2014, 564, 277-283. [CrossRef]

50. Akimoto, T.; Ueno, T.; Tsutsumi, Y.; Doi, H.; Hanawa, T.; Wakabayashi, N. Evaluation of corrosion resistance of implant-use Ti-Zr binary alloys with a range of compositions. J. Biomed. Mater. Res. Part B Appl. Biomater. 2018, 106, 73-79. [CrossRef] [PubMed]

51. Atalay, B.; Aybar, B.; Ergüven, M.; Emes, Y.; Bultan, Ö.; Akça, K.; Yalçin, S.; Baysal, U.; Işsever, H.; Çehreli, M.C.; et al. The effects of pulsed electromagnetic field (PEMF) on osteoblast-like cells cultured on titanium and titanium-zirconium surfaces. J. Craniofac. Surg. 2013, 24, 2127-2134. [CrossRef]

52. Pérez, R.A.; Gargallo, J.; Altuna, P.; Herrero-Climent, M.; Gil, F.J. Fatigue of narrow dental implants: Influence of the hardening method. Materials 2020, 13, 1429. [CrossRef] [PubMed]

53. Wang, B.; Ruan, W.; Liu, J.; Zhang, T.; Yang, H.; Ruan, J. Microstructure, mechanical properties, and preliminary biocompatibility evaluation of binary Ti-Zr alloys for dental application. J. Biomater. Appl. 2019, 33, 766-775. [CrossRef]

54. Hsu, H.C.; Wu, S.C.; Hsu, S.K.; Sung, Y.C.; Ho, W.F. Effects of heat treatments on the structure and mechanical properties of Zr-30Ti alloys. Mater. Charact. 2011, 62, 157-163. [CrossRef]

55. Byeli, A.V.; Kukareko, V.A.; Kononov, A.G. Titanium and zirconium based alloys modified by intensive plastic deformation and nitrogen ion implantation for biocompatible implants. J. Mech. Behav. Biomed. Mater. 2012, 6, 89-94. [CrossRef]

56. Jones, F.H. Teeth and bones: Applications of surface science to dental materials and related biomaterials. Surf. Sci. Rep. 2001, 42, 75-205. [CrossRef]

57. Filipović, U.; Dahmane, R.G.; Ghannouchi, S.; Zore, A.; Bohinc, K. Bacterial adhesion on orthopedic implants. Adv. Colloid Interface Sci. 2020, 283, 1-12. [CrossRef]

58. Shah, F.A.; Thomsen, P.; Palmquist, A. Osseointegration and current interpretations of the bone-implant interface. Acta Biomater 2019, 84, 1-15. [CrossRef]

59. Puleo, D.A.; Thomas, M.V. Implant Surfaces. Dent. Clin. N. Am. 2006, 50, 323-338. [CrossRef]

60. Agarwal, R.; García, A.J. Biomaterial strategies for engineering implants for enhanced osseointegration and bone repair. Adv. Drug Deliv. Rev. 2015, 94, 53-62. [CrossRef] [PubMed]

61. Hong, J.; Azens, A.; Ekdahl, K.N.; Granqvist, C.G.; Nilsson, B. Material-specific thrombin generation following contact between metal surfaces and whole blood. Biomaterials 2005, 26, 1397-1403. [CrossRef] [PubMed]

62. O'Brien, B.; Carroll, W. The evolution of cardiovascular stent materials and surfaces in response to clinical drivers: A review. Acta Biomater. 2009, 5, 945-958. [CrossRef]

63. Kurup, A.; Dhatrak, P.; Khasnis, N. Surface modification techniques of titanium and titanium alloys for biomedical dental applications: A review. Mater. Today Proc. 2020, 39, 84-90. [CrossRef]

64. Chang, Y.R.; Xu, F.F.; Li, J.; You, Y.H.; Liu, C.; Yin, L.H. Surface morphology and surface properties of Ti and TiZr implant materials. Zhonghua Kou Qiang Yi Xue Za Zhi 2019, 54, 118-123. [CrossRef] [PubMed]

65. Gittens, R.A.; Scheideler, L.; Rupp, F.; Hyzy, S.L.; Geis-Gerstorfer, J.; Schwartz, Z.; Boyan, B.D. A review on the wettability of dental implant surfaces II: Biological and clinical aspects. Acta Biomater. 2014, 10, 2907-2918. [CrossRef] [PubMed]

66. Ben-Nissan, B.; Choi, A.H.; Bendavid, A. Mechanical properties of inorganic biomedical thin films and their corresponding testing methods. Surf. Coat. Technol. 2013, 233, 39-48. [CrossRef]

67. Hanawa, T. Biofunctionalization of titanium for dental implant. Jpn. Dent. Sci. Rev. 2010, 46, 93-101. [CrossRef]

68. Stoian, A.B.; Demetrescu, I.; Ionita, D. Nanotubes and nano pores with chitosan construct on TiZr serving as drug reservoir. Colloids Surfaces B Biointerfaces 2020, 185, 110535. [CrossRef]

69. Ionita, D.; Grecu, M.; Ungureanu, C.; Demetrescu, I. Antimicrobial activity of the surface coatings on TiAlZr implant biomaterial. J. Biosci. Bioeng. 2011, 112, 630-634. [CrossRef]

70. Micksch, T.; Herrmann, E.; Scharnweber, D.; Schwenzer, B. A modular peptide-based immobilization system for $\mathrm{ZrO}_{2}$, TiZr and $\mathrm{TiO}_{2}$ surfaces. Acta Biomater. 2015, 12, 290-297. [CrossRef]

71. Wang, Y.; Yu, H.; Chen, C.; Zhao, Z. Review of the biocompatibility of micro-arc oxidation coated titanium alloys. Mater. Des. 2015, 85, 640-652. [CrossRef]

72. Mahapatro, A. Bio-functional nano-coatings on metallic biomaterials. Mater. Sci. Eng. C 2015, 55, 227-251. [CrossRef] 
73. Tan, D.; Zhou, S.; Qiu, J.; Khusro, N. Preparation of functional nanomaterials with femtosecond laser ablation in solution. J. Photochem. Photobiol. C Photochem. Rev. 2013, 17, 50-68. [CrossRef]

74. Jaworek, A.; Sobczyk, A.T. Electrospraying route to nanotechnology: An overview. J. Electrostat. 2008, 66, 197-219. [CrossRef]

75. Jaworek, A. Micro-and nanoparticle production by electrospraying. Powder Technol. 2007, 176, 18-35. [CrossRef]

76. Izquierdo, J.; Bolat, G.; Cimpoesu, N.; Trinca, L.C.; Mareci, D.; Souto, R.M. Electrochemical characterization of pulsed layer deposited hydroxyapatite-zirconia layers on Ti-21Nb-15Ta-6Zr alloy for biomedical application. Appl. Surf. Sci. 2016, 385, 368-378. [CrossRef]

77. Leite, D.M.C.; de Alencar, M.C.; Mucsi, C.S.; Araujo, J.V.S.; Tavares, L.A.; Berbel, L.O.; Aranha, L.C.; Rossi, J.L. Modifications of titanium and zirconium alloy surfaces for use as dental implants. Mater. Sci. Forum 2020, 1012, 477-482. [CrossRef]

78. Wang, W.; Li, Z.; Zhang, Z.; Dong, S.; Liu, Y. Atomic oxygen treatment effects on magnetron sputtered Zr-Ti binary films. Appl. Surf. Sci. 2015, 324, 669-676. [CrossRef]

79. Oliveira, N.T.C.; Biaggio, S.R.; Piazza, S.; Sunseri, C.; Di Quarto, F. Photo-electrochemical and impedance investigation of passive layers grown anodically on titanium alloys. Electrochim. Acta 2004, 49, 4563-4576. [CrossRef]

80. Habazaki, H.; Uozumi, M.; Konno, H.; Shimizu, K.; Nagata, S.; Asami, K.; Matsumoto, K.; Takayama, K.; Oda, Y.; Skeldon, P.; et al Influences of structure and composition on growth of anodic oxide films on Ti-Zr alloys. Electrochim. Acta 2003, 48, 3257-3266. [CrossRef]

81. Bolat, G.; Izquierdo, J.; Mareci, D.; Sutiman, D.; Souto, R.M. Electrochemical characterization of ZrTi alloys for biomedical applications. Part 2: The effect of thermal oxidation. Electrochim. Acta 2013, 106, 432-439. [CrossRef]

82. Cordeiro, J.M.; Faverani, L.P.; Grandini, C.R.; Rangel, E.C.; da Cruz, N.C.; Nociti Junior, F.H.; Almeida, A.B.; Vicente, F.B.; Morais, B.R.G.; Barão, V.A.R.; et al. Characterization of chemically treated Ti-Zr system alloys for dental implant application. Mater. Sci. Eng. C 2018, 92, 849-861. [CrossRef] [PubMed]

83. Sharma, A.; McQuillan, A.J.; Sharma, L.A.; Waddell, J.N.; Shibata, Y.; Duncan, W.J. Spark anodization of titanium-zirconium alloy: Surface characterization and bioactivity assessment. J. Mater. Sci. Mater. Med. 2015, 26. [CrossRef] [PubMed]

84. Frank, M.J.; Walter, M.S.; Bucko, M.M.; Pamula, E.; Lyngstadaas, S.P.; Haugen, H.J. Polarization of modified titanium and titanium-zirconium creates nano-structures while hydride formation is modulated. Appl. Surf. Sci. 2013, 282, 7-16. [CrossRef]

85. Cordeiro, J.M.; Pantaroto, H.N.; Paschoaleto, E.M.; Rangel, E.C.; da Cruz, N.C.; Sukotjo, C.; Barão, V.A.R. Synthesis of biofunctional coating for a TiZr alloy: Surface, electrochemical, and biological characterizations. Appl. Surf. Sci. 2018, 452, 268-278. [CrossRef]

86. Calderon Moreno, J.M.; Osiceanu, P.; Vasilescu, C.; Anastasescu, M.; Drob, S.I.; Popa, M. Obtaining, structural and corrosion characterization of anodized nanolayers on Ti-20Zr alloy surface. Surf. Coat. Technol. 2013, 235, 792-802. [CrossRef]

87. Kim, W.G.; Choe, H.C.; Ko, Y.M.; Brantley, W.A. Nanotube morphology changes for Ti-Zr alloys as Zr content increases. Thin Solid Films 2009, 517, 5033-5037. [CrossRef]

88. Trincă, L.C.; Mareci, D.; Souto, R.M.; Lozano-Gorrín, A.D.; Izquierdo, J.; Burtan, L.; Motrescu, I.; Vulpe, V.; Pavel, G.; Strungaru, S.; et al. Osseointegration evaluation of ZrTi alloys with hydroxyapatite-zirconia-silver layer in pig's tibiae. Appl. Surf. Sci. 2019, 487, 127-137. [CrossRef]

89. Pantazi, A.; Vardaki, M.; Mihai, G.; Ionita, D.; Stoian, A.B.; Enachescu, M.; Demetrescu, I. Understanding surface and interface properties of modified $\mathrm{Ti}_{50} \mathrm{Zr}$ with nanotubes. Appl. Surf. Sci. 2020, 506, 144661. [CrossRef]

90. Ion, R.; Stoian, A.B.; Dumitriu, C.; Grigorescu, S.; Mazare, A.; Cimpean, A.; Demetrescu, I.; Schmuki, P. Nanochannels formed on TiZr alloy improve biological response. Acta Biomater. 2015, 24, 370-377. [CrossRef] [PubMed]

91. Chen, X.; Li, Y.; Hodgson, P.D.; Wen, C. In vitro behavior of human osteoblast-like cells (SaOS2) cultured on surface modified titanium and titanium-zirconium alloy. Mater. Sci. Eng. C 2011, 31, 1545-1552. [CrossRef]

92. Wen, C.E.; Xu, W.; Hu, W.Y.; Hodgson, P.D. Hydroxyapatite/titania sol-gel coatings on titanium-zirconium alloy for biomedical applications. Acta Biomater. 2007, 3, 403-410. [CrossRef] [PubMed]

93. Prodana, M.; Nistor, C.E.; Stoian, A.B.; Ionita, D.; Burnei, C. Dual nanofibrous bioactive coatings on TiZr implants. Coatings 2020, 10, 526. [CrossRef]

94. Demetrescu, I.; Dumitriu, C.; Totea, G.; Nica, C.I.; Dinischiotu, A.; Ionita, D. Zwitterionic cysteine drug coating influence in functionalization of implantable $\mathrm{Ti}_{50} \mathrm{Zr}$ alloy for antibacterial, biocompatibility and stability properties. Pharmaceutics 2018, 10, 220. [CrossRef] [PubMed]

95. Vardaki, M.; Ionita, D.; Stoian, A.B.; Demetrescu, I. Increasing corrosion resistance of a ZrTi alloy with a bioinspired coating with low porosity. Mater. Corros. 2017, 68, 988-994. [CrossRef]

96. Matusiewicz, H. Potential release of in vivo trace metals from metallic medical implants in the human body: From ions to nanoparticles-A systematic analytical review. Acta Biomater. 2014, 10, 2379-2403. [CrossRef]

97. Cordeiro, J.M.; Beline, T.; Ribeiro, A.L.R.; Rangel, E.C.; da Cruz, N.C.; Landers, R.; Faverani, L.P.; Vaz, L.G.; Fais, L.M.G.; Vicente, F.B.; et al. Development of binary and ternary titanium alloys for dental implants. Dent. Mater. 2017, 33, 1244-1257. [CrossRef] [PubMed]

98. Chen, Q.; Thouas, G.A. Metallic implant biomaterials. Mater. Sci. Eng. R Reports 2015, 87, 1-57. [CrossRef]

99. Vasilescu, C.; Drob, S.I.; Neacsu, E.I.; Mirza Rosca, J.C. Surface analysis and corrosion resistance of a new titanium base alloy in simulated body fluids. Corros. Sci. 2012, 65, 431-440. [CrossRef]

100. Souto, R.M.; Burstein, G.T. A preliminary investigation into the microscopic depassivation of passive titanium implant materials in vitro. J. Mater. Sci. Mater. Med. 1996, 7, 337-343. [CrossRef] 
101. Burstein, G.T.; Liu, C.; Souto, R.M.; Vines, S.P. Origins of pitting corrosion. Corros. Eng. Sci. Technol. 2004, 39, 25-30. [CrossRef]

102. Burstein, G.T.; Souto, R.M. Observations of localised instability of passive titanium in chloride solution. Electrochim. Acta 1995, 40, 1881-1888. [CrossRef]

103. Burstein, G.T.; Liu, C.; Souto, R.M. The effect of temperature on the nucleation of corrosion pits on titanium in Ringer's physiological solution. Biomaterials 2005, 26, 245-256. [CrossRef] [PubMed]

104. Revathi, A.; Borrás, A.D.; Muñoz, A.I.; Richard, C.; Manivasagam, G. Degradation mechanisms and future challenges of titanium and its alloys for dental implant applications in oral environment. Mater. Sci. Eng. C. Mater. Biol. Appl. 2017, 76, 1354-1368. [CrossRef]

105. Izquierdo, J.; Mareci, D.; Bolat, G.; Santana, J.J.; Rodríguez-Raposo, R.; Fernández-Mérida, L.C.; Burtan, L.; Trincă, L.C.; Souto, R.M. Improvement of the corrosion resistance of biomedical zr-ti alloys using a thermal oxidation treatment. Metals 2020, 10. [CrossRef]

106. Mareci, D.; Bolat, G.; Cailean, A.; Santana, J.J.; Izquierdo, J.; Souto, R.M. Effect of acidic fluoride solution on the corrosion resistance of ZrTi alloys for dental implant application. Corros. Sci. 2014, 87, 334-343. [CrossRef]

107. Mareci, D.; Sutiman, D.; Chelariu, R.; Leon, F.; Curteanu, S. Evaluation of the corrosion resistance of new ZrTi alloys by experiment and simulation with an adaptive instance-based regression model. Corros. Sci. 2013, 73, 106-122. [CrossRef]

108. Bolat, G.; Izquierdo, J.; Santana, J.J.; Mareci, D.; Souto, R.M. Electrochemical characterization of ZrTi alloys for biomedical applications. Electrochim. Acta 2013, 88, 447-456. [CrossRef]

109. Izquierdo, J.; Bolat, G.; Mareci, D.; Munteanu, C.; González, S.; Souto, R.M. Electrochemical behaviour of ZrTi alloys in artificial physiological solution simulating in vitro inflammatory conditions. Appl. Surf. Sci. 2014, 313, 259-266. [CrossRef]

110. Calderon Moreno, J.M.; Vasilescu, E.; Drob, P.; Osiceanu, P.; Vasilescu, C.; Drob, S.I.; Popa, M. Surface analysis and electrochemical behavior of Ti-20Zr alloy in simulated physiological fluids. Mater. Sci. Eng. B Solid State Mater. Adv. Technol. 2013, 178, 1195-1204. [CrossRef]

111. Narendrakumar, K.; Kulkarni, M.; Addison, O.; Mazare, A.; Junkar, I.; Schmuki, P.; Sammons, R.; Iglič, A. Adherence of oral streptococci to nanostructured titanium surfaces. Dent. Mater. 2015, 31, 1460-1468. [CrossRef]

112. Elias, C.N.; Oshida, Y.; Lima, J.H.C.; Muller, C.A. Relationship between surface properties (roughness, wettability and morphology) of titanium and dental implant removal torque. J. Mech. Behav. Biomed. Mater. 2008, 1, 234-242. [CrossRef]

113. Roehling, S.; Astasov-Frauenhoffer, M.; Hauser-Gerspach, I.; Braissant, O.; Woelfler, H.; Waltimo, T.; Kniha, H.; Gahlert, M. In Vitro Biofilm Formation on Titanium and Zirconia Implant Surfaces. J. Periodontol. 2017, 88, 298-307. [CrossRef] [PubMed]

114. Siddiqui, D.A.; Guida, L.; Sridhar, S.; Valderrama, P.; Wilson, T.G.; Rodrigues, D.C. Evaluation of oral microbial corrosion on the surface degradation of dental implant materials. J. Periodontol. 2019, 90, 72-81. [CrossRef] [PubMed]

115. Chopra, D.; Gulati, K.; Ivanovski, S. Understanding and Optimizing the Antibacterial Functions of Anodized Nano-Engineered Titanium Implants. Acta Biomater. 2021. [CrossRef] [PubMed]

116. Antunes, R.A.; De Oliveira, M.C.L. Corrosion fatigue of biomedical metallic alloys: Mechanisms and mitigation. Acta Biomater 2012, 8, 937-962. [CrossRef] [PubMed]

117. Tejero, R.; Anitua, E.; Orive, G. Toward the biomimetic implant surface: Biopolymers on titanium-based implants for bone regeneration. Prog. Polym. Sci. 2014, 39, 1406-1447. [CrossRef]

118. Kaluderović, M.R.; Krajnović, T.; Maksimović-Ivanić, D.; Graf, H.L.; Mijatović, S. Ti-SLActive and TiZr-SLActive dental implant surfaces promote fast osteoblast differentiation. Coatings 2017, 7, 102. [CrossRef]

119. Marco, F.; Milena, F.; Gianluca, G.; Vittoria, O. Peri-implant osteogenesis in health and osteoporosis. Micron 2005, 36, 630-644. [CrossRef]

120. Cabrera-Domínguez, J.J.; Castellanos-Cosano, L.; Torres-Lagares, D.; Pérez-Fierro, M.; Machuca-Portillo, G. Clinical performance of titanium-zirconium implants with a hydrophilic surface in patients with controlled type 2 diabetes mellitus: 2-year results from a prospective case-control clinical study. Clin. Oral Investig. 2020, 24, 2477-2486. [CrossRef]

121. El-Sheikh, A.M.; Shihabuddin, O.F. Clinical and radiographic evaluation of narrow-diameter titanium-zirconium implants in unilateral atrophic mandibular distal extensions: A 1-year pilot study. J. Contemp. Dent. Pract. 2015, 15, 417-422. [CrossRef]

122. Herrmann, J.; Hentschel, A.; Glauche, I.; Vollmer, A.; Schlegel, K.A.; Lutz, R. Implant survival and patient satisfaction of reduced diameter implants made from a titanium-zirconium alloy: A retrospective cohort study with 550 implants in 311 patients. J. Cranio Maxillofac. Surg. 2016, 44, 1940-1944. [CrossRef]

123. Altinci, P.; Can, G.; Gunes, O.; Ozturk, C.; Eren, H. Stability and Marginal Bone Level Changes of SLActive Titanium-Zirconium Implants Placed with Flapless Surgery: A Prospective Pilot Study. Clin. Implant Dent. Relat. Res. 2016, 18, 1193-1199. [CrossRef]

124. Vardaki, M.; Mohajernia, S.; Pantazi, A.; Nica, I.C.; Enachescu, M.; Mazare, A.; Demetrescu, I.; Schmuki, P. Post treatments effect on TiZr nanostructures fabricated via anodizing. J. Mater. Res. Technol. 2019, 8, 5802-5812. [CrossRef]

125. Medvedev, A.E.; Molotnikov, A.; Lapovok, R.; Zeller, R.; Berner, S.; Habersetzer, P.; Dalla Torre, F. Microstructure and mechanical properties of Ti-15Zr alloy used as dental implant material. J. Mech. Behav. Biomed. Mater. 2016, 62, 384-398. [CrossRef]

126. Hotchkiss, K.M.; Sowers, K.T.; Olivares-Navarrete, R. Novel in vitro comparative model of osteogenic and inflammatory cell response to dental implants. Dent. Mater. 2019, 35, 176-184. [CrossRef]

127. Murphy, M.; Walczak, M.S.; Thomas, A.G.; Silikas, N.; Berner, S.; Lindsay, R. Toward optimizing dental implant performance: Surface characterization of Ti and TiZr implant materials. Dent. Mater. 2017, 33, 43-53. [CrossRef] [PubMed] 
128. Frank, M.J.; Walter, M.S.; Lyngstadaas, S.P.; Wintermantel, E.; Haugen, H.J. Hydrogen content in titanium and a titaniumzirconium alloy after acid etching. Mater. Sci. Eng. C 2013, 33, 1282-1288. [CrossRef] [PubMed]

129. Ivanova, A.A.; Surmeneva, M.A.; Shugurov, V.V.; Koval, N.N.; Shulepov, I.A.; Surmenev, R.A. Physico-mechanical properties of Ti-Zr coatings fabricated via ion-assisted arc-plasma deposition. Vacuum 2018, 149, 129-133. [CrossRef]

130. Lin, M.T.; Wan, C.H.; Wu, W. Characterization and corrosion resistance of TiZr coating on SS304 stainless steel using cathodic arc evaporation techniques. Surf. Coat. Technol. 2017, 320, 217-225. [CrossRef]

131. Romanov, D.A.; Sosnin, K.V.; Filyakov, A.D.; Nevskii, S.A.; Moskovskii, S. V The effect of bioinert electroexplosive coatings on stress distribution near the dental implant-bone interface. Mater. Res. Express 2021, 8. [CrossRef]

132. Tsai, M.T.; Chang, Y.Y.; Huang, H.L.; Wu, Y.H.; Shieh, T.M. Micro-arc oxidation treatment enhanced the biological performance of human osteosarcoma cell line and human skin fibroblasts cultured on titanium-zirconium films. Surf. Coat. Technol. 2016, 303, 268-276. [CrossRef]

133. Shin, K.R.; Ko, Y.G.; Shin, D.H. Surface characteristics of $\mathrm{ZrO}_{2}$-containing oxide layer in titanium by plasma electrolytic oxidation in K 4P $2 \mathrm{O} 7$ electrolyte. J. Alloys Compd. 2012, 536, S226-S230. [CrossRef]

134. Oleshko, O.; Deineka, V.; Husak, Y.; Korniienko, V.; Dryhval, B.; Dudko, J.; Solodovnyk, O.; Simka, W.; Michalska, J.; Mishchenko, O.; et al. Plasma Electrolytic Oxidation of TiZr Alloy in ZnONPs-Contained Solution: Structural and Biological Assessment. In Springer Proceedings in Physics; Springer: Berlin/Heidelberg, Germany, 2020; Volume 244, pp. 75-82, ISBN 9789811539954.

135. Wang, X.; Fan, H.; Zhang, F.; Zhao, S.; Liu, Y.; Xu, Y.; Wu, R.; Li, D.; Yang, Y.; Liao, L.; et al. Antibacterial Properties of Bilayer Biomimetic Nano-ZnO for Dental Implants. ACS Biomater. Sci. Eng. 2020, 6, 1880-1886. [CrossRef] [PubMed]

136. Simonenko, E.P.; Simonenko, N.P.; Kopitsa, G.P.; Mokrushin, A.S.; Khamova, T.V.; Sizova, S.V.; Khaddazh, M.; Tsvigun, N.V.; Pipich, V.; Gorshkova, Y.E.; et al. A sol-gel synthesis and gas-sensing properties of finely dispersed $\mathrm{ZrTiO}_{4}$. Mater. Chem. Phys. 2019, 225, 347-357. [CrossRef]

137. Souza, J.C.M.; Sordi, M.B.; Kanazawa, M.; Ravindran, S.; Henriques, B.; Silva, F.S.; Aparicio, C.; Cooper, L.F. Nano-scale modification of titanium implant surfaces to enhance osseointegration. Acta Biomater. 2019, 94, 112-131. [CrossRef]

138. Viswanathan, V.; Laha, T.; Balani, K.; Agarwal, A.; Seal, S. Challenges and advances in nanocomposite processing techniques. Mater. Sci. Eng. R Rep. 2006, 54, 121-285. [CrossRef]

139. Byrappa, K.; Adschiri, T. Hydrothermal technology for nanotechnology. Prog. Cryst. Growth Charact. Mater. 2007, 53, 117-166. [CrossRef]

140. Kumar, A.P.; Depan, D.; Singh Tomer, N.; Singh, R.P. Nanoscale particles for polymer degradation and stabilization-Trends and future perspectives. Prog. Polym. Sci. 2009, 34, 479-515. [CrossRef]

141. Bauer, S.; Schmuki, P.; von der Mark, K.; Park, J. Engineering biocompatible implant surfaces: Part I: Materials and surfaces. Prog. Mater. Sci. 2013, 58, 261-326. [CrossRef]

142. Manole, C.C.; Dinischiotu, A.; Nica, C.; Demetrescu, I.; Pirvu, C. Influence of electrospun $\mathrm{TiO}_{2}$ nanowires on corrosion resistance and cell response of Ti ${ }_{50} \mathrm{Zr}$ alloy. Mater. Corros. 2018, 69, 1609-1619. [CrossRef]

143. Mendonça, G.; Mendonça, D.B.S.; Aragão, F.J.L.; Cooper, L.F. Advancing dental implant surface technology-From micron-to nanotopography. Biomaterials 2008, 29, 3822-3835. [CrossRef] [PubMed]

144. Geetha, M.; Singh, A.K.; Asokamani, R.; Gogia, A.K. Ti based biomaterials, the ultimate choice for orthopaedic implants-A review. Prog. Mater. Sci. 2009, 54, 397-425. [CrossRef]

145. Sarraf, M.; Nasiri-Tabrizi, B.; Yeong, C.H.; Madaah Hosseini, H.R.; Saber-Samandari, S.; Basirun, W.J.; Tsuzuki, T. Mixed oxide nanotubes in nanomedicine: A dead-end or a bridge to the future? Ceram. Int. 2021, 47, 2917-2948. [CrossRef] [PubMed]

146. Frandsen, C.J.; Brammer, K.S.; Noh, K.; Connelly, L.S.; Oh, S.; Chen, L.H.; Jin, S. Zirconium oxide nanotube surface prompts increased osteoblast functionality and mineralization. Mater. Sci. Eng. C 2011, 31, 1716-1722. [CrossRef]

147. Neacsu, P.; Mazare, A.; Cimpean, A.; Park, J.; Costache, M.; Schmuki, P.; Demetrescu, I. Reduced inflammatory activity of RAW 264.7 macrophages on titania nanotube modified Ti surface. Int. J. Biochem. Cell Biol. 2014, 55, 187-195. [CrossRef]

148. Minagar, S.; Berndt, C.C.; Wang, J.; Ivanova, E.; Wen, C. A review of the application of anodization for the fabrication of nanotubes on metal implant surfaces. Acta Biomater. 2012, 8, 2875-2888. [CrossRef]

149. Grigorescu, S.; Pruna, V.; Titorencu, I.; Jinga, V.V.; Mazare, A.; Schmuki, P.; Demetrescu, I. The two step nanotube formation on TiZr as scaffolds for cell growth. Bioelectrochemistry 2014, 98, 39-45. [CrossRef] [PubMed]

150. Stoian, A.B.; Vardaki, M.; Ionita, D.; Enachescu, M.; Prodana, M.; Brancoveanu, O.; Demetrescu, I. Nanopores and nanotubes ceramic oxides elaborated on titanium alloy with zirconium by changing anodization potentials. Ceram. Int. 2018, 44, 7026-7033. [CrossRef]

151. Ion, R.; Mazare, A.; Dumitriu, C.; Pirvu, C.; Schmuki, P.; Cimpean, A. Nanochannelar topography positively modulates osteoblast differentiation and inhibits osteoclastogenesis. Coatings 2018, 8, 294. [CrossRef]

152. Liu, X.; Chu, P.K.; Ding, C. Surface nano-functionalization of biomaterials. Mater. Sci. Eng. R Rep. 2010, 70, 275-302. [CrossRef]

153. Wang, D.; Bierwagen, G.P. Sol-gel coatings on metals for corrosion protection. Prog. Org. Coat. 2009, 64, 327-338. [CrossRef]

154. Vardaki, M.; Romonti, D.C.; Ionita, D.; Demetrescu, I. Polymeric hybrid coatings on Ti50\%Zr alloy. Mater. Plast. 2016, 53, 276-279.

155. Mareci, D.; Trincă, L.C.; Căilean, D.; Souto, R.M. Corrosion resistance of ZrTi alloys with hydroxyapatite-zirconia-silver layer in simulated physiological solution containing proteins for biomaterial applications. Appl. Surf. Sci. 2016, 389, 1069-1075. [CrossRef]

156. Padovani, G.C.; Feitosa, V.P.; Sauro, S.; Tay, F.R.; Durán, G.; Paula, A.J.; Durán, N. Advances in Dental Materials through Nanotechnology: Facts, Perspectives and Toxicological Aspects. Trends Biotechnol. 2015, 33, 621-636. [CrossRef] 
157. Rai, M.; Yadav, A.; Gade, A. Silver nanoparticles as a new generation of antimicrobials. Biotechnol. Adv. 2009, 27, 76-83. [CrossRef] [PubMed]

158. Ionita, D.; Grecu, M.; Ungureanu, C.; Demetrescu, I. Modifying the TiAlZr biomaterial surface with coating, for a better anticorrosive and antibacterial performance. Appl. Surf. Sci. 2011, 257, 9164-9168. [CrossRef]

159. Micksch, T.; Liebelt, N.; Scharnweber, D.; Schwenzer, B. Investigation of the peptide adsorption on $\mathrm{ZrO}_{2}, \mathrm{TiZr}$, and $\mathrm{TiO}{ }_{2}$ surfaces as a method for surface modification. ACS Appl. Mater. Interfaces 2014, 6, 7408-7416. [CrossRef] [PubMed]

160. Zhao, B.; Van Der Mei, H.C.; Subbiahdoss, G.; De Vries, J.; Rustema-Abbing, M.; Kuijer, R.; Busscher, H.J.; Ren, Y. Soft tissue integration versus early biofilm formation on different dental implant materials. Dent. Mater. 2014, 30, 716-727. [CrossRef]

161. Kunrath, M.F.; Monteiro, M.S.G.; Gupta, S.; Hubler, R.; de Oliveira, S.D. Influence of titanium and zirconia modified surfaces for rapid healing on adhesion and biofilm formation of Staphylococcus epidermidis. Arch. Oral Biol. 2020, 117. [CrossRef]

162. Galli, S.; Jimbo, R.; Naito, Y.; Berner, S.; Dard, M.; Wennerberg, A. Chemically modified titanium-zirconium implants in comparison with commercially pure titanium controls stimulate the early molecular pathways of bone healing. Clin. Oral Implants Res. 2017, 28, 1234-1240. [CrossRef]

163. Gallagher, W.M.; Lynch, I.; Allen, L.T.; Miller, I.; Penney, S.C.; O'Connor, D.P.; Pennington, S.; Keenan, A.K.; Dawson, K.A. Molecular basis of cell-biomaterial interaction: Insights gained from transcriptomic and proteomic studies. Biomaterials 2006, 27, 5871-5882. [CrossRef]

164. Souza, J.G.S.; Bertolini, M.; Costa, R.C.; Lima, C.V.; Barão, V.A.R. Proteomic profile of the saliva and plasma protein layer adsorbed on Ti-Zr alloy: The effect of sandblasted and acid-etched surface treatment. Biofouling 2020, 36, 428-441. [CrossRef]

165. Chen, S.; Tsoi, J.K.H.; Tsang, P.C.S.; Park, Y.-J.; Song, H.-J.; Matinlinna, J.P. Candida albicans aspects of binary titanium alloys for biomedical applications. Regen. Biomater. 2020, 7, 213-220. [CrossRef] [PubMed]

166. Gómez-Florit, M.; Xing, R.; Ramis, J.M.; Taxt-Lamolle, S.; Haugen, H.J.; Lyngstadaas, S.P.; Monjo, M. Human gingival fibroblasts function is stimulated on machined hydrided titanium zirconium dental implants. J. Dent. 2014, 42, 30-38. [CrossRef] [PubMed]

167. Piattelli, A.; Farias Pontes, A.E.; Degidi, M.; Iezzi, G. Histologic studies on osseointegration: Soft tissues response to implant surfaces and components. A review. Dent. Mater. 2011, 27, 53-60. [CrossRef] [PubMed]

168. Sista, S.; Wen, C.; Hodgson, P.D.; Pande, G. Expression of cell adhesion and differentiation related genes in MC3T3 osteoblasts plated on titanium alloys: Role of surface properties. Mater. Sci. Eng. C 2013, 33, 1573-1582. [CrossRef] [PubMed]

169. Bordin, D.; Cavalcanti, I.M.G.; Jardim Pimentel, M.; Fortulan, C.A.; Sotto-Maior, B.S.; Del Bel Cury, A.A.; da Silva, W.J. Biofilm and saliva affect the biomechanical behavior of dental implants. J. Biomech. 2015, 48, 997-1002. [CrossRef]

170. Pachaiappan, R.; Rajendran, S.; Show, P.L.; Manavalan, K.; Naushad, M. Metal/metal oxide nanocomposites for bactericidal effect: A review. Chemosphere 2020, 128607. [CrossRef]

171. Huang, H.L.; Chang, Y.Y.; Liu, J.X.; Tsai, M.T.; Lai, C.H. Antibacterial activity and cell compatibility of TiZrN, TiZrCN, and TiZr-amorphous carbon coatings. Thin Solid Films 2015, 596, 111-117. [CrossRef]

172. Sánchez, M.C.; Llama-Palacios, A.; Fernández, E.; Figuero, E.; Marín, M.J.; León, R.; Blanc, V.; Herrera, D.; Sanz, M. An in vitro biofilm model associated to dental implants: Structural and quantitative analysis of in vitro biofilm formation on different dental implant surfaces. Dent. Mater. 2014, 30, 1161-1171. [CrossRef] [PubMed]

173. Han, A.; Tsoi, J.K.H.; Rodrigues, F.P.; Leprince, J.G.; Palin, W.M. Bacterial adhesion mechanisms on dental implant surfaces and the influencing factors. Int. J. Adhes. Adhes. 2016, 69, 58-71. [CrossRef]

174. Myshin, H.L.; Wiens, J.P. Factors affecting soft tissue around dental implants: A review of the literature. J. Prosthet. Dent. 2005, 94, 440-444. [CrossRef] [PubMed]

175. Ungureanu, C.; Pirvu, C.; Mindroiu, M.; Demetrescu, I. Antibacterial polymeric coating based on polypyrrole and polyethylene glycol on a new alloy TiAlZr. Prog. Org. Coat. 2012, 75, 349-355. [CrossRef]

176. Al-Radha, A.S.D.; Dymock, D.; Younes, C.; O'Sullivan, D. Surface properties of titanium and zirconia dental implant materials and their effect on bacterial adhesion. J. Dent. 2012, 40, 146-153. [CrossRef] [PubMed]

177. Al-Ahmad, A.; Wiedmann-Al-Ahmad, M.; Fackler, A.; Follo, M.; Hellwig, E.; Bächle, M.; Hannig, C.; Han, J.S.; Wolkewitz, M.; Kohal, R. In vivo study of the initial bacterial adhesion on different implant materials. Arch. Oral Biol. 2013, 58, $1139-1147$. [CrossRef] [PubMed]

178. Gulati, K.; Hamlet, S.M.; Ivanovski, S. Tailoring the immuno-responsiveness of anodized nano-engineered titanium implants. J. Mater. Chem. B 2018, 6, 2677-2689. [CrossRef]

179. Yang, Y.; Liu, L.; Luo, H.; Zhang, D.; Lei, S.; Zhou, K. Dual-Purpose Magnesium-Incorporated Titanium Nanotubes for Combating Bacterial Infection and Ameliorating Osteolysis to Realize Better Osseointegration. ACS Biomater. Sci. Eng. 2019, 5, $5368-5383$. [CrossRef]

180. Huo, K.; Zhang, X.; Wang, H.; Zhao, L.; Liu, X.; Chu, P.K. Osteogenic activity and antibacterial effects on titanium surfaces modified with Zn-incorporated nanotube arrays. Biomaterials 2013, 34, 3467-3478. [CrossRef]

181. Rahnamaee, S.Y.; Bagheri, R.; Heidarpour, H.; Vossoughi, M.; Golizadeh, M.; Samadikuchaksaraei, A. Nanofibrillated chitosan coated highly ordered titania nanotubes array/graphene nanocomposite with improved biological characters. Carbohydr. Polym. 2021, 254, 117465. [CrossRef]

182. Prokopovich, P. Interactions between mammalian cells and nano-or micro-sized wear particles: Physico-chemical views against biological approaches. Adv. Colloid Interface Sci. 2014, 213, 36-47. [CrossRef]

183. Hanawa, T. Metal ion release from metal implants. Mater. Sci. Eng. C 2004, 24, 745-752. [CrossRef] 
184. Hanawa, T. Evaluation techniques of metallic biomaterials in vitro. Sci. Technol. Adv. Mater. 2002, 3, 289-295. [CrossRef]

185. Park, Y.J.; Song, Y.H.; An, J.H.; Song, H.J.; Anusavice, K.J. Cytocompatibility of pure metals and experimental binary titanium alloys for implant materials. J. Dent. 2013, 41, 1251-1258. [CrossRef]

186. Mazare, A.; Totea, G.; Burnei, C.; Schmuki, P.; Demetrescu, I.; Ionita, D. Corrosion, antibacterial activity and haemocompatibility of $\mathrm{TiO}_{2}$ nanotubes as a function of their annealing temperature. Corros. Sci. 2016, 103, 215-222. [CrossRef]

187. Grigorescu, S.; Ungureanu, C.; Kirchgeorg, R.; Schmuki, P.; Demetrescu, I. Various sized nanotubes on TiZr for antibacterial surfaces. Appl. Surf. Sci. 2013, 270, 190-196. [CrossRef]

188. Lyndon, J.A.; Boyd, B.J.; Birbilis, N. Metallic implant drug/device combinations for controlled drug release in orthopaedic applications. J. Control. Release 2014, 179, 63-75. [CrossRef]

189. Jabed, A.; Khan, M.M.; Camiller, J.; Greenlee-Wacker, M.; Haider, W.; Shabib, I. Property optimization of Zr-Ti-X (X = Ag, Al) metallic glass via combinatorial development aimed at prospective biomedical application. Surf. Coat. Technol. 2019, 372, $278-287$. [CrossRef]

190. Huang, C.H.; Huang, Y.S.; Lin, Y.S.; Lin, C.H.; Huang, J.C.; Chen, C.H.; Li, J.B.; Chen, Y.H.; Jang, J.S.C. Electrochemical and biocompatibility response of newly developed TiZr-based metallic glasses. Mater. Sci. Eng. C 2014, 43, 343-349. [CrossRef]

191. Heimann, R.B. Thermal spraying of biomaterials. Surf. Coat. Technol. 2006, 201, 2012-2019. [CrossRef]

192. Jimbo, R.; Naito, Y.; Galli, S.; Berner, S.; Dard, M.; Wennerberg, A. Biomechanical and Histomorphometrical Evaluation of TiZr Alloy Implants: An in vivo Study in the Rabbit. Clin. Implant Dent. Relat. Res. 2015, 17, e670-e678. [CrossRef] [PubMed]

193. Wen, B.; Zhu, F.; Li, Z.; Zhang, P.; Lin, X.; Dard, M. The osseointegration behavior of titanium-zirconium implants in ovariectomized rabbits. Clin. Oral Implants Res. 2014, 25, 819-825. [CrossRef]

194. Yin, L.; Chang, Y.; You, Y.; Liu, C.; Li, J.; Lai, H. Biological responses of human bone mesenchymal stem cells to Ti and TiZr implant materials. Clin. Implant Dent. Relat. Res. 2019, 21, 550-564. [CrossRef]

195. Ghazal, S.; Huynh-Ba, G.; Aghaloo, T.; Dibart, S.; Froum, S.; O’Neal, R.; Cochran, D. Randomized Controlled Multicenter Clinical Study Evaluating Crestal Bone Level Change of Narrow-Diameter Versus Standard-Diameter Ti-Zr Implants for Single Tooth Replacement in Anterior and Premolar Region. Int. J. Oral Maxillofac. Implants 2019, 34, 708-718. [CrossRef]

196. Quirynen, M.; Al-Nawas, B.; Meijer, H.J.A.; Razavi, A.; Reichert, T.E.; Schimmel, M.; Storelli, S.; Romeo, E.; Bräuer, I.; Castro-Laza, J.; et al. Small-diameter titanium Grade IV and titanium-zirconium implants in edentulous mandibles: Three-year results from a double-blind, randomized controlled trial. Clin. Oral Implants Res. 2015, 26, 831-840. [CrossRef]

197. Müller, F.; Al-Nawas, B.; Storelli, S.; Quirynen, M.; Hicklin, S.; Castro-Laza, J.; Bassetti, R.; Schimmel, M. Small-diameter titanium grade IV and titanium-zirconium implants in edentulous mandibles: Five-year results from a double-blind, randomized controlled trial. BMC Oral Health 2015, 15, 1-10. [CrossRef]

198. Zheng, X.; Mo, A. Immune System-Related Diseases and Dental Implant Treatment. In Dental Implant Treatment in Medically Compromised Patients; Springer International Publishing: Cham, Switzerland, 2020; pp. 129-147, ISBN 9783030285562.

199. Karl, M.; Krafft, T.; Kelly, J. Fracture of a Narrow-Diameter Roxolid Implant: Clinical and Fractographic Considerations. Int. J. Oral Maxillofac. Implants 2014, 29, 1193-1196. [CrossRef]

200. Rahmati, M.; Lyngstadaas, S.P.; Reseland, J.E.; Andersbakken, I.; Haugland, H.S.; López-Peña, M.; Cantalapiedra, A.G.; Guzon Muñoz, F.M.; Haugen, H.J. Coating doxycycline on titanium-based implants: Two in vivo studies. Bioact. Mater. 2020, 5, 787-797. [CrossRef]

201. Walter, M.S.; Frank, M.J.; Satué, M.; Monjo, M.; Rønold, H.J.; Lyngstadaas, S.P.; Haugen, H.J. Bioactive implant surface with electrochemically bound doxycycline promotes bone formation markers in vitro and in vivo. Dent. Mater. 2014, 30, $200-214$. [CrossRef]

202. Mendonça, G.; Mendonça, D.B.S.; Simões, L.G.P.; Araújo, A.L.; Leite, E.R.; Golin, A.L.; Aragão, F.J.L.; Cooper, L.F. Nanostructured implant surface effect on osteoblast gene expression and bone-to-implant contact in vivo. Mater. Sci. Eng. C 2011, 31, 1809-1818. [CrossRef]

203. Sharma, A.; McQuillan, A.J.; Shibata, Y.; Sharma, L.A.; Waddell, J.N.; Duncan, W.J. Histomorphometric and histologic evaluation of titanium-zirconium (aTiZr) implants with anodized surfaces. J. Mater. Sci. Mater. Med. 2016, 27. [CrossRef] [PubMed] 